\title{
Characterisation of sub-micron particle number concentrations and formation events in the western Bushveld Igneous Complex, South Africa
}

\author{
A. Hirsikko ${ }^{1,2}$, V. Vakkari² ${ }^{2}$ P. Tiitta ${ }^{3,4}$, H. E. Manninen ${ }^{2}$, S. Gagné2, ${ }^{*, * *}$, H. Laakso ${ }^{2}$, M. Kulmala ${ }^{2}$, A. Mirme ${ }^{5}$, \\ S. Mirme $^{5}$, D. Mabaso ${ }^{6}$, J. P. Beukes ${ }^{4}$, and L. Laakso ${ }^{1,4}$ \\ ${ }^{1}$ Finnish Meteorological Institute, Research and Development, P.O. Box 503, 00101, Finland \\ ${ }^{2}$ Department of Physics, University of Helsinki, P.O. Box 64, University of Helsinki, 00014, Finland \\ ${ }^{3}$ University of Eastern Finland, PL 1627, 70211, Kuopio, Finland \\ ${ }^{4}$ School of Physical and Chemical Sciences, North-West University, Potchefstroom, South Africa \\ ${ }^{5}$ Institute of Physics, University of Tartu, 18 Ülikooli Str., 50090 Tartu, Estonia \\ ${ }^{6}$ Rustenburg Local Municipality, Rustenburg, South Africa \\ *now at: Environment Canada, Toronto, Ontario, M3H5T4, Canada \\ ** now at: Dalhousie University, Halifax, Nova Scotia, B3H3J5, Canada
}

Correspondence to: A. Hirsikko (anne.hirsikko@fmi.fi)

Received: 10 January 2012 - Published in Atmos. Chem. Phys. Discuss.: 20 January 2012

Revised: 3 April 2012 - Accepted: 13 April 2012 - Published: 4 May 2012

\begin{abstract}
South Africa holds significant mineral resources, with a substantial fraction of these reserves occurring and being processed in a large geological structure termed the Bushveld Igneous Complex (BIC). The area is also highly populated by informal, semi-formal and formal residential developments. However, knowledge of air quality and research related to the atmosphere is still very limited in the area. In order to investigate the characteristics and processes affecting sub-micron particle number concentrations and formation events, air ion and aerosol particle size distributions and number concentrations, together with meteorological parameters, trace gases and particulate matter (PM) were measured for over two years at Marikana in the heart of the western BIC. The observations showed that trace gas (i.e. $\mathrm{SO}_{2}$, $\mathrm{NO}_{\mathrm{x}}, \mathrm{CO}$ ) and black carbon concentrations were relatively high, but in general within the limits of local air quality standards. The area was characterised by very high condensation sink due to background aerosol particles, $\mathrm{PM}_{10}$ and $\mathrm{O}_{3}$ concentration. The results indicated that high amounts of Aitken and accumulation mode particles originated from domestic burning for heating and cooking in the morning and evening, while during daytime $\mathrm{SO}_{2}$-based nucleation followed by the growth by condensation of vapours from in-
\end{abstract}

dustrial, residential and natural sources was the most probable source for large number concentrations of nucleation and Aitken mode particles. Nucleation event day frequency was extremely high, i.e. $86 \%$ of the analysed days, which to the knowledge of the authors is the highest frequency ever reported. The air mass back trajectory and wind direction analyses showed that the secondary particle formation was influenced both by local and regional pollution and vapour sources. Therefore, our observation of the annual cycle and magnitude of the particle formation and growth rates during nucleation events were similar to results previously published for a semi-clean savannah site in South Africa.

\section{Introduction}

Aerosol particles may affect climate directly by scattering and reflecting radiation, or indirectly via cloud-aerosol interactions (Lohmann and Feichter, 2005; Myhre, 2009; Quaas et al., 2009; Hand and Malm, 2007; IPCC, 2007). Aerosol particles are also known to have an influence on human health and, in polluted environments, particles pose a serious health 
threat for the population (e.g. Pope and Dockery, 2006; Russell and Brunekreef, 2009; Breitner et al., 2011).

Particle sources and formation mechanisms have been intensively studied (e.g. Kulmala et al., 2004, 2011), but the number of observations in the developing world is still very limited. Previously, such observations have been carried out in Mexico City (Mexico), Beijing (China), New Delhi (India), Gaborone (Botswana) (e.g. Jayaratne and Verma, 2001; Dunn et al., 2004; Mönkkönen et al., 2004, 2005; Yue et al., 2009; Wu et al., 2008, 2011; Kalafut-Pettibone et al., 2011) and a few other sites. To our knowledge, there are no previous observations of ultrafine particle number concentrations or size distributions from residential areas in southern Africa. However, in a relatively clean background savannah area in South Africa new particle formation has been studied by Laakso et al. (2008) and Vakkari et al. (2011). These studies revealed new particle formation taking place every sunny day throughout the year. As new particle formation was found to be a regional phenomenon (Laakso et al., 2008; Vakkari et al., 2011), it is expected that new particle formation will also occur in polluted areas.

South Africa holds major mineral assets. A significant proportion of these reserves are located in a geological structure known as the Bushveld Igneous Complex (BIC), out of which ca. $80 \%$ and $45 \%$ of the world's platinum group metals (PGMs) and chromium, respectively, are produced (Cramer et al., 2004; Xiao and Laplante, 2004; Beukes et al., 2010). The most important use of PGMs is for the production of catalytic converters in automotive exhaust systems, which improve air quality. The chromium produced in this region is mostly in the form of ferrochrome (a crude alloy between iron and chromium), which in turn is mostly used for the production of stainless steel, a vital modern alloy. The BIC is divided into five different limbs, of which the western limb is the most intensely mined and industrialised. In a recent study it has been proposed that the western BIC should be declared as an air pollution hotspot by the South African government (Scott, 2010). However, notwithstanding the international importance of the western BIC in terms of the supply of commodities critical for the modern day society, nor the afore-mentioned indication that air quality in this region might be problematic, very little has been published in the peer reviewed scientific literature on atmospheric related matters for the western BIC.

Due to the lure of employment in the mining and metallurgical sectors in the western BIC, the area is populated by informal and semi-formal settlements. The observations discussed in this paper were carried out in a semi-informal and informal residential area at Marikana village in the heart of the western BIC, as part of an atmospheric research and air quality monitoring project initiated in 2006 (Laakso et al., 2008). Recently, Venter et al. (2012) analysed sources and temporal variation of gaseous compounds and particulate matter $\left(\mathrm{PM}_{10}\right)$ at Marikana. The aims of this work were to investigate the characteristic behaviour of sub-micron par- ticles by investigating ion and particle concentrations, as well as new particle formation based on nucleation event classification, formation and growth rate analyses. As far as the authors could asses, this is the first paper investigating submicron and ultrafine particle characteristics and new particle formation in this internationally important area. Additionally, the measurement site also afforded the opportunity to investigate the interaction of pollution from semi-formal and informal settlements, with that of mining and pyrometallurgical industries.

\section{Site description}

The measurements at Marikana $\left(25^{\circ} 41^{\prime} 54.51^{\prime \prime} \mathrm{S}\right.$ and $27^{\circ} 28^{\prime} 50.05^{\prime \prime} \mathrm{E}, 1170 \mathrm{~m}$ a.s.1.) were carried out from 8 February 2008 to 17 May 2010. Venter et al. (2012) gave a detailed description of the measurement site and its location, which is therefore not repeated here. In general, the Rustenburg-Brits mining and residential area is located in a shallow valley surrounded by mountains rising $500 \mathrm{~m}$ above the central area. The valley is approximately $60 \mathrm{~km}$ long in west-east direction and $20-30 \mathrm{~km}$ wide in north-south direction. Figure 1 shows the location of Marikana within a regional context. The extent of the BIC in central South Africa and the location of major point sources (i.e. pyrometallurgical smelters) within the western BIC are also indicated in Fig. 1. Additionally, the Google image shows the immediate surroundings of the measurement site. The distributions of semi-formal and informal settlements in the immediate vicinity of the measurement site are indicated on this image with white blocks.

On the Highveld of South Africa two distinct seasonal periods can be identified, i.e. dry and wet periods, from May to September and October to April, respectively. The dry period (winter and adjacent months on autumn and spring) is characterised by cold nights and low relative humidity with no rain for several months, while during the wet period (summer and adjacent months in autumn and spring) the air is warm and heavy rains, especially in the form of thunderstorms, occur.

\section{Measurements}

All the measurements were carried out from a specially fitted trailer. The trailer and measurement devices have been introduced by Laakso et al. (2008), Vakkari et al. (2011) and Venter at al. (2012). Here we only give a short summary of the devices relevant for this specific study. To ensure data quality, the different instruments were compared against reference instruments at Hyytiälä, Finland before transportation to South Africa. 

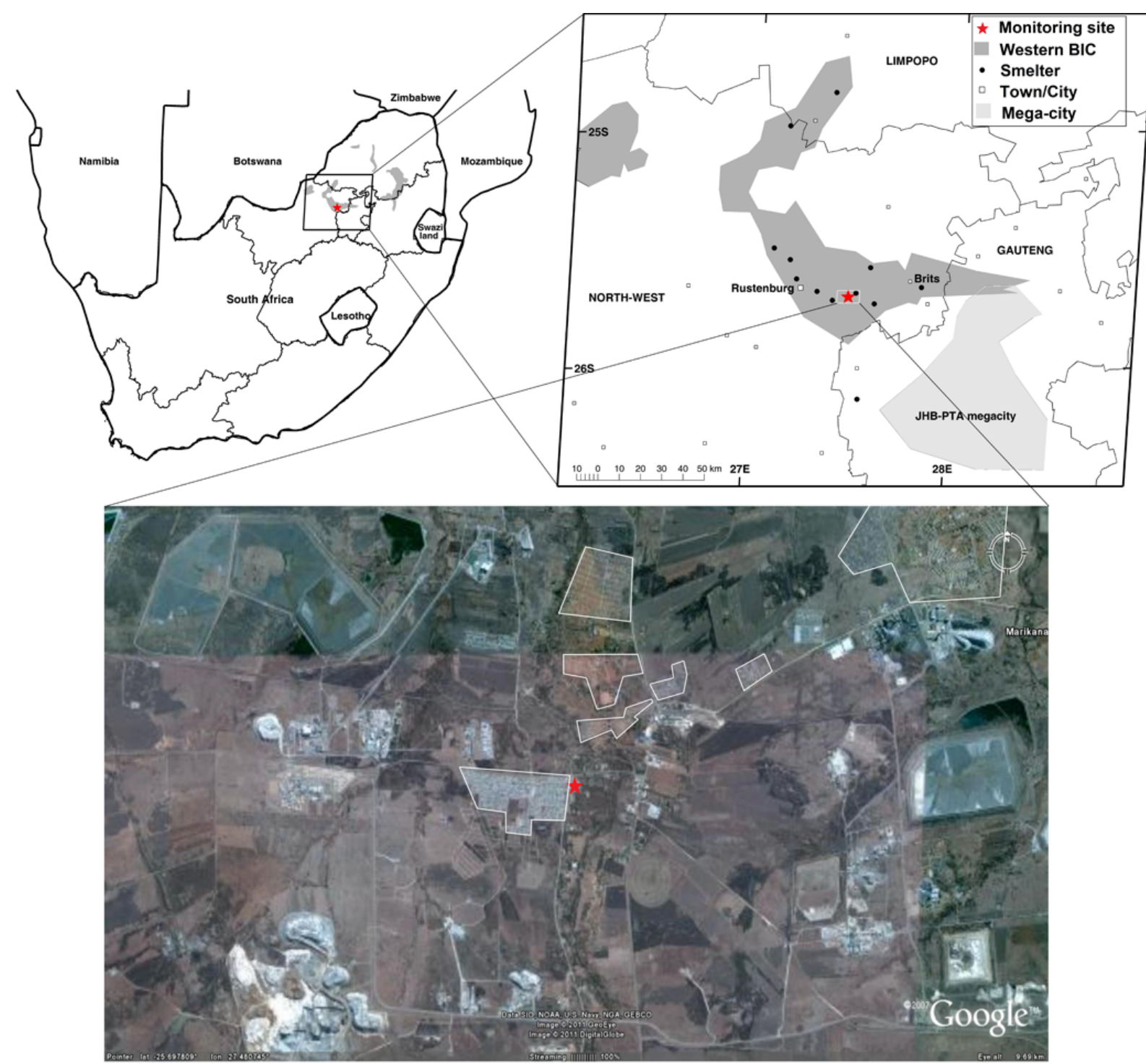

Fig. 1. A geographical map of southern Africa indicating the extent of the Bushveld Igneous Complex (BIC, in grey). The enlarged section of the geographical map indicates the western BIC, the proximity of the Johannesburg/Pretoria mega-city and the location of major point sources (pyrometallurgical smelters) in the western BIC. The Google map indicates the immediate surroundings of the measurement site $\left(25^{\circ} 41^{\prime} 54.51^{\prime \prime} \mathrm{S}\right.$ and $\left.27^{\circ} 28^{\prime} 50.05^{\prime \prime} \mathrm{E}\right)$. The white outlined blocks indicate the occurrence of informal and semi-formal residential settlements in-between the mining and metallurgical industries.

\subsection{Ion and particle size distribution measurements}

An Air Ion Spectrometer (AIS, Mirme et al., 2007) measures naturally charged air ions in the mobility range 3.2$0.0013 \mathrm{~cm}^{2} \mathrm{~V}^{-1} \mathrm{~s}^{-1}$, which corresponds to diameter range of ca. $0.8-42 \mathrm{~nm}$. The AIS consists of two identical cylindrically symmetric differential mobility analysers (DMA), each with 21 electrometers. One DMA measures the positive ion spectrum and the other DMA measures the negative ion spectrum simultaneously. The air that flows through each DMA consists of a sample $(30 \mathrm{lpm})$ and sheath $(60 \mathrm{lpm})$ flow. These air flows are controlled by ball valves, which are placed after the DMAs, and measured by venturi tubes, which include a dense grid to produce laminar flow. The AIS data is averaged and recorded in five minute cycles. The accuracy of the AIS data of this specific measurement campaign will be discussed in Sect. 4.1.

The aerosol particle size distributions were measured with a Differential Mobility Particle Sizer (DMPS) in the diameter range $10-840 \mathrm{~nm}$. The DMPS had a $28 \mathrm{~cm}$ long Vienna-type DMA (Winklmayr et al., 1991), a condensation particle counter (TSI 3010, Mertes, 1995) and it operated in a closed loop configuration (Hoppel, 1978; Jokinen and Mäkelä, 1997). The aerosol sample was dried with a 
Permapure MD-110-48 (Permapure LLC, USA) to less than $30 \%$ relative humidity, which was also continuously monitored. The total concentration obtained with this CPC was compared to a reference CPC (TSI 3772). The difference between the two CPCs was $7 \%$, which was considered in the data inversion.

\subsection{Supporting data}

Ancillary data included gas concentrations and basic meteorological parameters. For ozone $\left(\mathrm{O}_{3}\right)$ concentration monitoring, an Environment S.A. analyser (O341M) was deployed, correspondingly sulphur dioxide $\left(\mathrm{SO}_{2}\right)$ concentrations were monitored with Thermo analyser (Thermo Environmental Instruments Inc. model $43 \mathrm{~S})$, nitrogen oxides $\left(\mathrm{NO}_{\mathrm{x}}\right)$ concentrations with a Teledyne analyser (Teledyne Instruments API model 200AU), black carbon (BC) concentrations with a multi-angle absorption photometer (MAAP, model 5012), and carbon monoxide (CO) with a Horiba analyser (Horiba APMA 360). Temperature and relative humidity were measured with Rotronic (MP 101A), while wind speed and direction were measured with Vector equipment (A101ML and A200P/L, respectively). Additionally, particulate matter concentrations (i.e. $\mathrm{PM}_{1}, \mathrm{PM}_{2.5}$ and $\mathrm{PM}_{10}$ ) were monitored and trace metal content of the particulate matter is also available, although only discussion of the $\mathrm{PM}_{10}$ is included in this work.

\section{Methods}

Data measured both with the AIS and the DMPS included some gaps or bad data, which were due to malfunctioning of the instruments, as well as service and/or calibrations being conducted. Before data analysis commenced, raw data was cleaned according to methods indicated by Laakso et al. (2008) and Venter et al. (2012). Aerosol data was cleaned by visually selecting and deleting periods and size intervals when data was noisy or otherwise suspicious. Gas data was corrected based on in-situ calibration procedures. All the data was averaged over $15 \mathrm{~min}$. However, as higher temporal resolution particle and ion data are needed for the formation and growth rate analysis, the original time resolution of DMPS (9 min) and AIS (5 min) data were kept.

\subsection{Effect of flow rate and contamination on size distributions obtained with the AIS}

During the measurements at Marikana we noticed that the air pathways of the AIS got partially blocked due to the accumulation of soot and coarse particles, mainly in the areas with small apertures and on the venturi tube nets (for a technical drawing of AIS, please see Mirme et al., 2007). Fortunately no particulate build-up occurred in the blower. As a result of accumulation of particulate matter, the flow rates of the two DMAs may become different over time, since both of

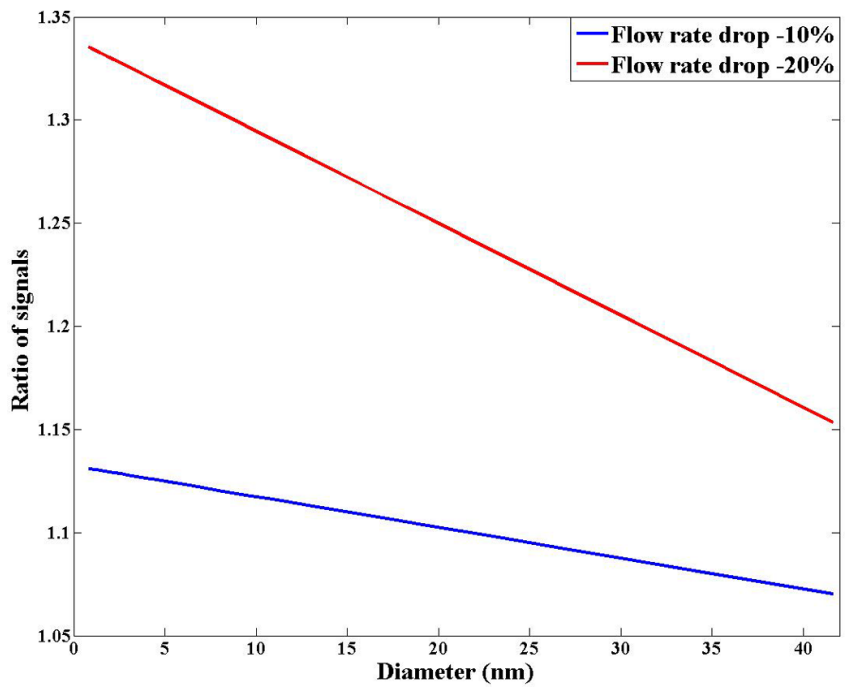

Fig. 2. Ratio of raw signals during normal flow rate to reduced flow rate. The peak signal and both adjacent signals from the electrometers were included in the analysis.

the DMAs have their own post-venturi air flow paths. The sheath air flow rates were also affected by blockages in the nets before the electrical filters, which produce ion free air.

Decreasing flow rate broadens and shifts mobility distributions. The best way to correct the data would have been to calculate new transfer functions, which correspond to new flow rates. However, we were uncertain of the relative changes of the different flows (i.e. two sheath flows, two sample flows and a combined exhaust flow), since only the combined exhaust flow rate was recorded by default. All the individual flow rates were measured only after the measurement campaign at Marikana was completed. These post campaign measurements indicated that the decrease of all flows were proportional. Due to the limited amount of knowledge on the effect of reduced flow rates on the mobility distribution, we conducted theoretical and experimental studies to evaluate the effect.

The theoretical investigation included calculation of ion currents (i.e. raw data) as a function of the electrometer number using the AIS inversion algorithm by reducing the flow rate by 10,20 and $30 \%$ of the expected value. For simplicity, we assumed that the sheath and sample flow rates in both analysers dropped proportionally, which may not always be the case and requires further experimental investigation. The results showed that the small ion (less than ca. $1.9 \mathrm{~nm}$ in diameter) distribution was immediately shifted towards smaller sizes when flow rate began to decrease. However, the distributions of larger ions (ca. $>3 \mathrm{~nm}$ ) began to shift only when flow rates had decreased by ca. $30 \%$ or more. Signals of the electrometers in all sizes decreased immediately with any decrease in flow rate (Fig. 2). The ratios in Fig. 2 were obtained by including signal readings of three adjacent electrometers, which are taken into account in the data inversion. 


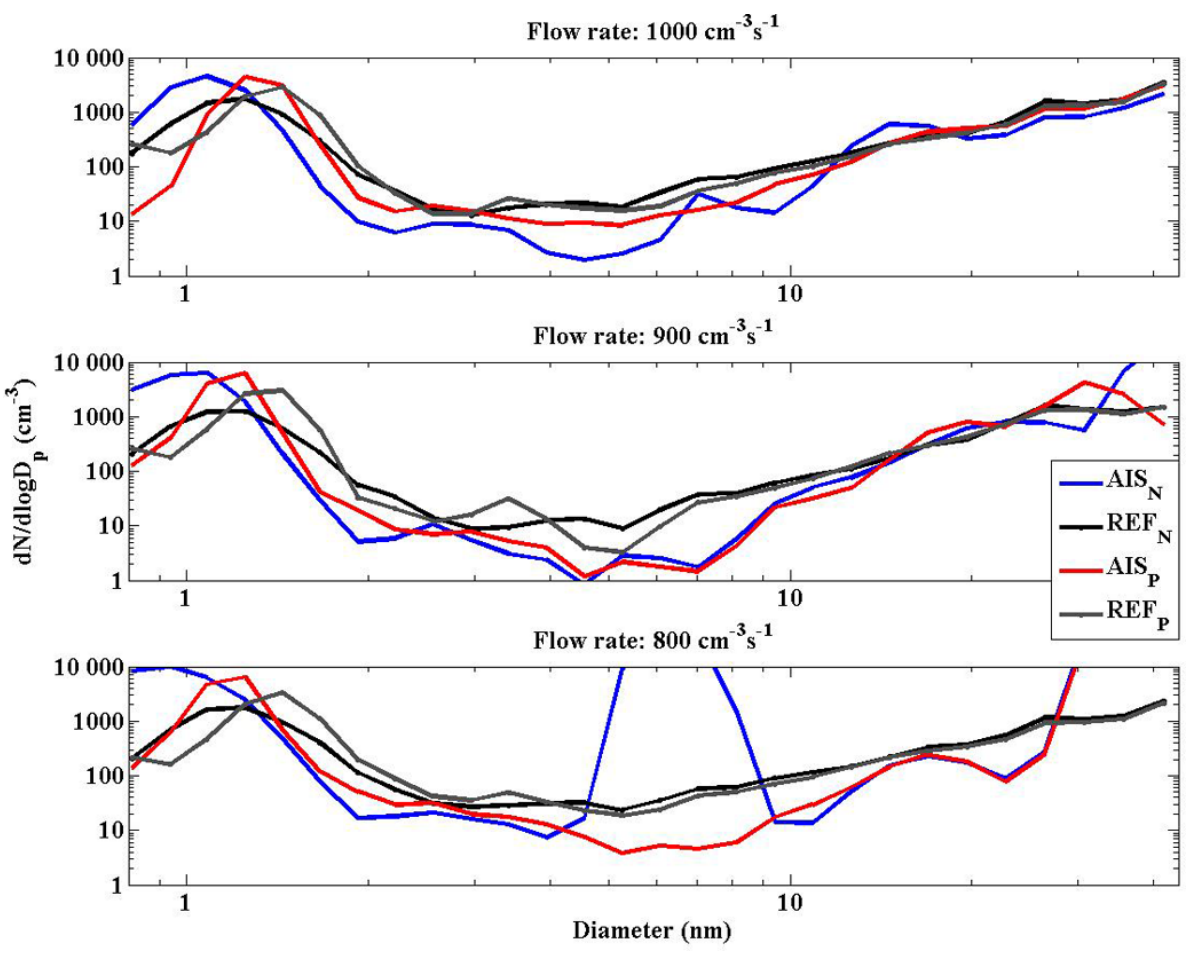

Fig. 3. Average size distributions measured with the AIS and a reference ion spectrometer at different flow rates during flow rate experiments. The negative polarity is symbolised with the letter $\mathrm{N}$ and the positive polarity with $\mathrm{P}$.

Experimental investigation carried out in Finland in MayJune 2010 included both laboratory calibration and field study. The laboratory calibrations are explained and analysed in detail by Gagné et al. (2011). The results showed that the AIS (serial nr. 2 utilised here) classified the mobility accurately. However, the AIS overestimated concentrations compared to a reference instrument. The concentration difference was almost constant and independent of size. We therefore calculated a correction factor for concentration based on the calibration.

The second experiment was to reduce flow rates artificially by burning a paraffin torch, which generated soot and coarse particles, close to the inlet. In this way, the out flow rate was decreased by 10 and $20 \%$. The observations (Fig. 3) confirmed the results from the theoretical evaluation (Fig. 2). Upon reduced flow, small ion mode immediately began shifting towards smaller sizes. Larger particle distribution shift could not be identified with the applied flow rates and method. However, concentrations of ions in all size ranges dropped with reduced flow. The functioning of the AIS electrometers eventually became unstable as an increased amount of soot gathered on their surfaces, therefore, only a qualitative comparison was possible.

Based on the above-mentioned results, it was decided to use the AIS data as follows: (1) sub- $3 \mathrm{~nm}$ ion data was used only if the flow rate was at the desired level $(60 \mathrm{lpm} \pm 5 \%)$, (2) data of ions larger than $3 \mathrm{~nm}$ in diameter were used if the flow rate had decreased by at most $20 \%$, and (3) all the data affected by high electrometer noise (due to the accumulation of dirt on the electrometers) were excluded. After selecting the data based on the flow rate we were able to analyse $14 \%$ and $78 \%$ of the data of sub- $3 \mathrm{~nm}$ and larger than $3 \mathrm{~nm}$ ions, respectively. The data cleaning removed large fraction of data for ions larger than $10 \mathrm{~nm}$ in diameter during the wet period (see Sect. 5.3).

Additionally, we multiplied the entire positive and negative ion spectrum having diameters larger than $3 \mathrm{~nm}$ with concentration correction factors of 0.76 and 0.79 , respectively, which were obtained based on the calibration with the reference instrument (Gagné et al., 2011). An alteration to the inversion procedure was implemented on 7 May 2008 and the calibration was valid for the applied inversion procedure. Therefore only AIS data from 7 May 2008 to 17 May 2010 (end of the sampling campaign at Marikana) is analysed and considered further in this paper. Due to above-presented data corrections we utilised the good quality ion data $(14 \%$ of all data) when presenting diurnal cycles of concentrations (Sect. 5.1), and the data acquired during periods of reduced flow rate (up to a maximum of $20 \%$ flow drop) only when classifying the particle formation events (Sect. 5.2) and analysing the growth rates (Sect. 5.3). 


\subsection{Altitude and temperature effects on the AIS data}

Our measurements were performed at a relatively high altitude (1170 $\mathrm{m}$ a.s.1.), where annual average temperature and pressure were $19^{\circ} \mathrm{C}$ and $886 \mathrm{hPa}$, respectively. The mobility of an ion depends on both ambient pressure and temperature. Thus at higher altitudes the ions may become more mobile compared to sea level. In this work we decided to use the Millikan diameter conversion (Millikan, 1923) for both the ion and particle datasets. Following the convention in previous publications (e.g. Manninen et al., 2010; Vakkari et al., 2011; Hirsikko et al., 2011 and references therein), the ion diameters were adjusted to average summer temperature $\left(23^{\circ} \mathrm{C}\right)$ at sea level $(1000 \mathrm{hPa})$, while the diameters of the DMPS data were calculated by using instant temperature and pressure inside the DMA. This led to a ca. $6 \%$ underestimation of the ion diameters compared to diameters of DMPS size distribution data. This small discrepancy in derived diameters due to different temperature and pressure scheme is small compared to other sources of uncertainty.

\subsection{Data analysis}

\subsubsection{Particle formation}

Particle formation events were classified visually according to guidelines by Yli-Juuti et al. (2009) and Vakkari et al. (2011) for the AIS data and by Dal Maso et al. (2005) for the DMPS data. We divided days into particle formation (i.e. nucleation), undefined and non-event days. Our aim was to analyse formation and growth rates for all nucleation events if possible, therefore no further division of particle formation events were made. Based on our earlier experience we know that this type of visual classification is subject to small discrepancies due to the judgement of the analyst(s).

Due to accuracy issues of concentration measurements and lack of sub-3 nm ion data (as discussed in Sect. 4.1) we were unable to calculate formation rates for 2-nm ions $\left(J_{2}\right)$ as is typically done when investigating particle formation processes (e.g. Kulmala et al., 2007; Manninen et al., 2010). The DMPS system was set to measure particles larger than $10 \mathrm{~nm}$ in diameter. Unfortunately, the lowest size channel of the DMPS had to be rejected as the DMPS high voltage power source could not keep the voltage stable below $8 \mathrm{~V}$. Therefore we began our analysis of formation and growth rates from $12 \mathrm{~nm}$ (i.e. $J_{12}$ and $\mathrm{GR}_{12-30}$ ).

Formation rates for $12 \mathrm{~nm}$ particles $\left(J_{12}\right)$ were calculated following Dal Maso et al. (2005, and references therein):

$J_{12}=\frac{\mathrm{d} N_{12-30}}{\mathrm{~d} t}+\operatorname{CoagS} \cdot N_{12-30}+F_{\text {growth }}$.

Where $N_{12-30}$ is the concentration of nucleation mode particles obtained by the DMPS, CoagS the particle removal rate due to coagulation and $F_{\text {growth }}$ is the flux of particle growth out of the nucleation mode. The latter was assumed to be equal to zero due to the assumption that particles do not grow larger than $30 \mathrm{~nm}$ during the time the nucleation event is investigated (Dal Maso et al., 2005).

\subsubsection{Particle growth}

We estimated the growth rates of particle population based on AIS and DMPS data. Ion growth rates from the AIS were analysed by using a maximum concentration method described by Hirsikko et al. (2005). The method follows the timing of maximum concentration of every size bin, and the growth rates are obtained as a slope of a linear fit to timediameter pairs. However, this method works best when the growing mode is narrow enough (i.e. for sub- $20 \mathrm{~nm}$ particle mode). Therefore, we calculated growth rates based on the DMPS data by using a mode fitting method introduced by Hussein et al. (2005) and Dal Maso et al. (2005). The mode fitting method cannot typically be used to estimate initial growth, thus the fitting often begins close to a diameter of $5 \mathrm{~nm}$, which makes this method unsuitable for growth rate analysis with the AIS data.

Major error sources for growth rate analysis are the stretching of size distributions due to decreasing flow rates in the AIS (as discussed in Sect. 4.1) and an inhomogeneous/changing air mass during a growth event. The first source of error was taken into account by using only data measured when the flow rates were high enough. The later effect was dealt with by visually checking how well the obtained slope followed the growing mode.

The analysis by Yli-Juuti et al. (2011) showed that the maximum concentration method typically results in somewhat higher growth rates than the mode fitting method. This was assumed to be due to high and changing coagulation sinks during growth, especially if the growth is slow (Leppä et al., 2011). However, growth rates at Marikana were high (Sect. 5.3), which reduced somewhat the possible overestimation. The obtained growth rates also depend on the instrument and the charge polarity of the particles (Yli-Juuti et al., 2011). The first arises from inaccurate determinations of flow rates, and the latter is due to the combination of the fact that activation of one charge polarity occurs before the other and continuous charging in the atmosphere. We will present growth and formation rates statistically, therefore qualitative error estimation is assumed to be sufficient for our purposes.

\subsubsection{Estimation of $\mathrm{H}_{2} \mathrm{SO}_{4}$ concentration and air mass back trajectories}

There are strong indications that sulphuric acid is involved in the atmospheric particle formation and growth (e.g. Weber et al., 1996; Fiedler et al., 2005; Sihto et al., 2006; Riipinen et al., 2007; Kuang et al., 2008; Sipilä, 2010; Paasonen et al., 2010; Brus et al., 2011). Vakkari et al. (2011) also observed that the nucleation event day frequency correlated with the temporal cycle of the sulphuric acid proxy concentrations 
in a semi-clean South African savannah. Several proxies for sulphuric acid have been derived (Petäjä et al., 2009; Mikkonen et al., 2011). However, none of them have been tested against sulphuric acid data from environments comparable to Marikana. We decided to deploy parameterisation by Petäjä et al. (2009), as was previously done by Vakkari et al. (2011):

$\left[\mathrm{H}_{2} \mathrm{SO}_{4}\right]_{p}=1.4 \times 10^{-7} \cdot \mathrm{Glob}^{-0.70} \cdot \frac{\left[\mathrm{SO}_{2}\right] \cdot \mathrm{Glob}}{\mathrm{CS}}$.

Where Glob indicates global radiation in $\mathrm{W} \mathrm{m}^{-2},\left[\mathrm{SO}_{2}\right]$ is the concentration in molecules $\mathrm{cm}^{-3}$ and CS is a condensation sink (in $\mathrm{s}^{-1}$ ) due to background aerosol particles. The condensation sink was calculated based on particle size distribution data according to Dal Maso et al. (2005, and references therein). While utilising the proxy developed for the clean Finnish background station, it should be kept in mind that there is no confirmation it works for the conditions at Marikana. Thus the absolute values are uncertain and most probably only the difference between the seasons can be considered reliable.

In addition to source and sink rates of nucleating and condensing vapours, particle formation is also affected by turbulent mixing of the boundary layer, as well as air mass origin and path. We, therefore, calculated 96-h air mass back trajectories in one hour resolution with a model (Hybrid Singleparticle Lagrangian Integrated Trajectory-HYSPLIT version 4.8) by the National Oceanic and Atmospheric Administration (Draxler and Hess, 2004; Air Resources Laboratory, 2011).

\section{Results}

A summary of daytime (08:00-14:00) gaseous and particulate pollutant concentrations at Marikana during the measurement period is shown in Table 1. As reported by Venter et al. (2012), the measured concentrations of $\mathrm{SO}_{2}, \mathrm{NO}_{\mathrm{x}}, \mathrm{CO}$ and $\mathrm{BC}$ were relatively high but generally within the limits of European and South African air quality standards. The concentrations of $\mathrm{O}_{3}$ and $\mathrm{PM}_{10}$ were observed to exceed regulations frequently.

\subsection{Variation of particle number concentration}

The concentrations of Aitken (20-100 nm in diameter) and accumulation (100-840 $\mathrm{nm}$ in diameter) mode particles had a clear annual cycle, i.e. concentrations were higher during the dry period compared to the wet period (Fig. 4). Median diurnal cycles (Fig. 5) indicated that the accumulation mode had peaks in the morning (06:30-08:00) and evening (19:0021:00), while the Aitken mode had three peak periods, i.e. the first in the morning (06:00-07:30), the second in the afternoon (11:00-14:30) and the third in the evening (18:3020:00). However, the timing of the concentration peaks was related to the duration of daylight and followed the length
Table 1. Median, 95th and 5th percentiles of global radiation, trace gas and estimated sulphuric acid concentrations, particle mass (in prevailing conditions) and black carbon mass concentrations during 08:00-14:00 local time on particle formation and undefined days, which classification was based on the DMPS data. Only median value is presented on non-event day.

\begin{tabular}{|c|c|c|c|}
\hline & $\begin{array}{l}\text { Event: } \\
\text { median } \\
95 \% \\
5 \%\end{array}$ & $\begin{array}{l}\text { Undefined: } \\
\text { median } \\
95 \% \\
5 \%\end{array}$ & $\begin{array}{l}\text { Non-event: } \\
\text { median }\end{array}$ \\
\hline $\mathrm{CS}\left(10^{-2} \mathrm{~s}^{-1}\right)$ & $\begin{array}{l}0.89 \\
2.17 \\
0.23\end{array}$ & $\begin{array}{l}0.74 \\
1.8 \\
0.11\end{array}$ & 0.89 \\
\hline $\begin{array}{l}{\left[\mathrm{H}_{2} \mathrm{SO}_{4}\right]_{p}} \\
\left(10^{6} \text { molec. } \mathrm{cm}^{-3}\right)\end{array}$ & $\begin{array}{l}6.2 \\
31.2 \\
0.8\end{array}$ & $\begin{array}{l}3.2 \\
16.4 \\
0.5\end{array}$ & 3.1 \\
\hline $\mathrm{SO}_{2}(\mathrm{ppb})$ & $\begin{array}{l}2.4 \\
18.1 \\
0.2\end{array}$ & $\begin{array}{l}1.4 \\
9.3 \\
0.1\end{array}$ & 2.3 \\
\hline $\mathrm{O}_{3}(\mathrm{ppb})$ & $\begin{array}{l}22.4 \\
60.1 \\
2.3\end{array}$ & $\begin{array}{l}22.7 \\
54.0 \\
3.3\end{array}$ & 25.1 \\
\hline $\mathrm{NO}_{\mathrm{x}}(\mathrm{ppb})$ & $\begin{array}{l}8.0 \\
38.1 \\
1.8\end{array}$ & $\begin{array}{l}6.5 \\
28.2 \\
1.6\end{array}$ & 9.2 \\
\hline $\mathrm{CO}(\mathrm{ppb})$ & $\begin{array}{l}189 \\
472 \\
101\end{array}$ & $\begin{array}{l}181 \\
434 \\
98\end{array}$ & 182 \\
\hline $\operatorname{GLOB}\left(\mathrm{W} \mathrm{m}^{-2}\right)$ & $\begin{array}{l}489 \\
971 \\
137\end{array}$ & $\begin{array}{l}421 \\
907 \\
126\end{array}$ & 156 \\
\hline $\mathrm{PM}_{10}\left(\mu \mathrm{g} \mathrm{m}^{-3}\right)$ & $\begin{array}{l}26.6 \\
74.6 \\
7.6\end{array}$ & $\begin{array}{l}26.8 \\
69.6 \\
8.1\end{array}$ & 32.4 \\
\hline $\mathrm{BC}\left(\mu \mathrm{g} \mathrm{m}^{-3}\right)$ & $\begin{array}{l}1.2 \\
4.1 \\
0.3\end{array}$ & $\begin{array}{l}1.0 \\
3.2 \\
0.3\end{array}$ & $\mathrm{NaN}$ \\
\hline
\end{tabular}

of the day. Nucleation mode $(12-20 \mathrm{~nm}$ in diameter) particle concentrations also had three concentration peaks during the day, the most important being at or before midday (Fig. 5). However, nucleation mode particle concentrations did not show as clear annual cycle as was seen with larger particles (Fig. 4).

We also calculated small and nucleation mode ion concentrations during the period when the AIS flow rate was at the desired level (Fig. 6). The small ion concentrations were observed to follow the evolution of the mixing layer height, while as was expected, nucleation and Aitken mode ion concentration showed similar diurnal cycle as was shown 


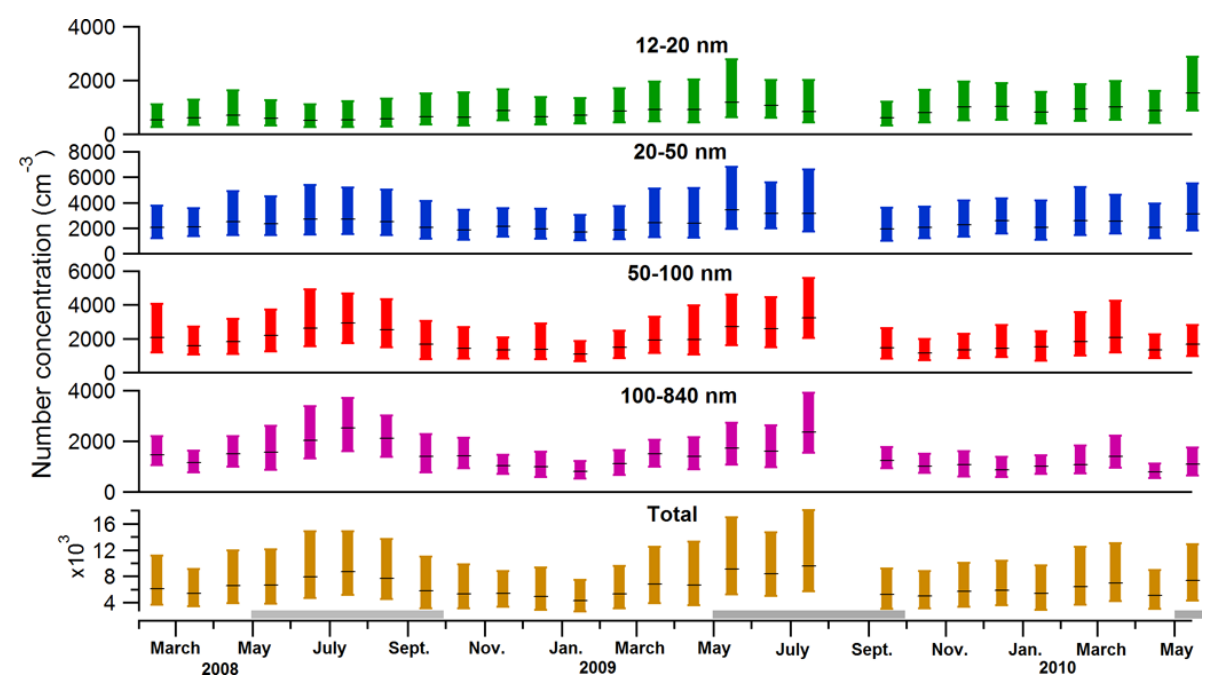

Fig. 4. Monthly median, $25 \%$ and $75 \%$ percentile concentrations of $12-20 \mathrm{~nm}, 20-50,50-100 \mathrm{~nm}, 100-840 \mathrm{~nm}$, and $12-840 \mathrm{~nm}$ (total) particles over two years. The dry periods are indicated with grey bars at the bottom of the figure.

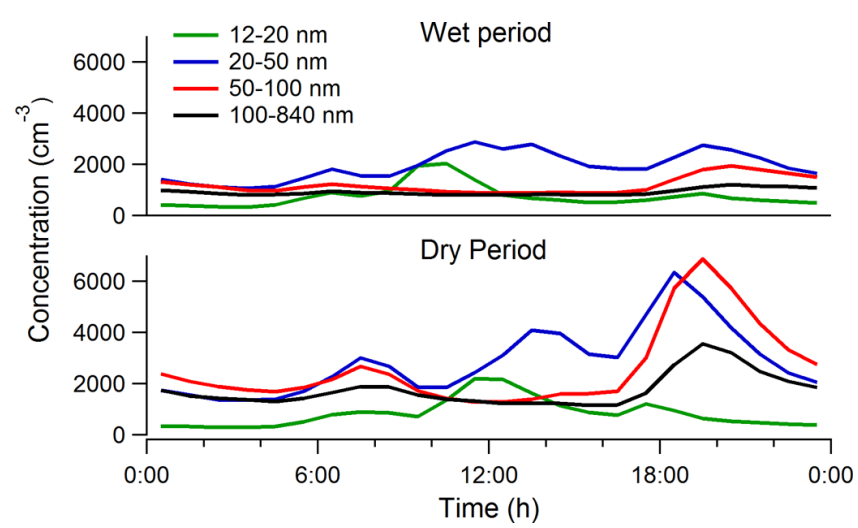

Fig. 5. Diurnal cycle of $12-20 \mathrm{~nm}, 20-50,50-100 \mathrm{~nm}$ and $100-$ $840 \mathrm{~nm}$ particle concentrations during the wet (October-April, upper panel) and the dry (May-September, lower panel) periods.

in Fig. 5. The concentrations of ions larger than $3 \mathrm{~nm}$ in diameter reflected the number concentration measured with the DMPS. The median small ion concentrations were $320 \mathrm{~cm}^{-3}$ and $450 \mathrm{~cm}^{-3}$ for positive and negative small ions respectively, which are typical for polluted environments (Hirsikko et al., 2011).

Condensation sink, which is mainly caused by large particles, may be used as a tracer for air quality. The CS values were high and typical for polluted urban or industrial environments (e.g. Mönkkönen et al., 2005; Kulmala et al., 2005; Yue et al., 2009). The CS had a clear annual cycle with maximum values during the dry period (Fig. 7), which was in accordance to observations by Vakkari et al. (2011) in the South African savannah.

Venter et al. (2012) indicated that $\mathrm{NO}_{\mathrm{x}}, \mathrm{CO}, \mathrm{BC}$ and particulate mass mainly originated from local residential com-
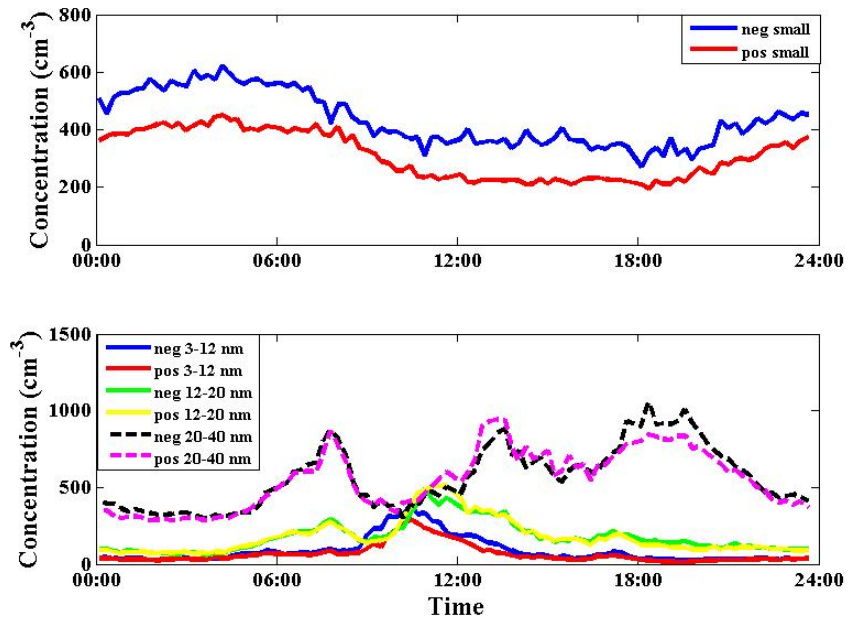

Fig. 6. Median diurnal concentrations: small ion concentrations are shown in the upper panel and concentrations of nucleation mode and $20-40 \mathrm{~nm}$ ions are presented in the lower panel.

bustion for heating and cooking at Marikana, while $\mathrm{SO}_{2}$ mainly originated from high stack industry emissions. Correlation coefficients between nucleation, Aitken and accumulation mode particle concentrations and trace gas, $\mathrm{BC}$ and $\mathrm{CS}$ are presented in Table 2. In addition, the relationship between particle and $\mathrm{SO}_{2}$ concentrations are shown in Fig. 8 . These observations together with the temporal variation of the particle number concentrations indicate that the morning and evening concentration peaks (Fig. 5) were due to the local residential combustion rather than due to industrial emissions. During the dry periods, which correspond to winter and the colder autumn and spring months, domestic burning is a major particle source. Residential combustion mainly takes place during the early morning and evening. 

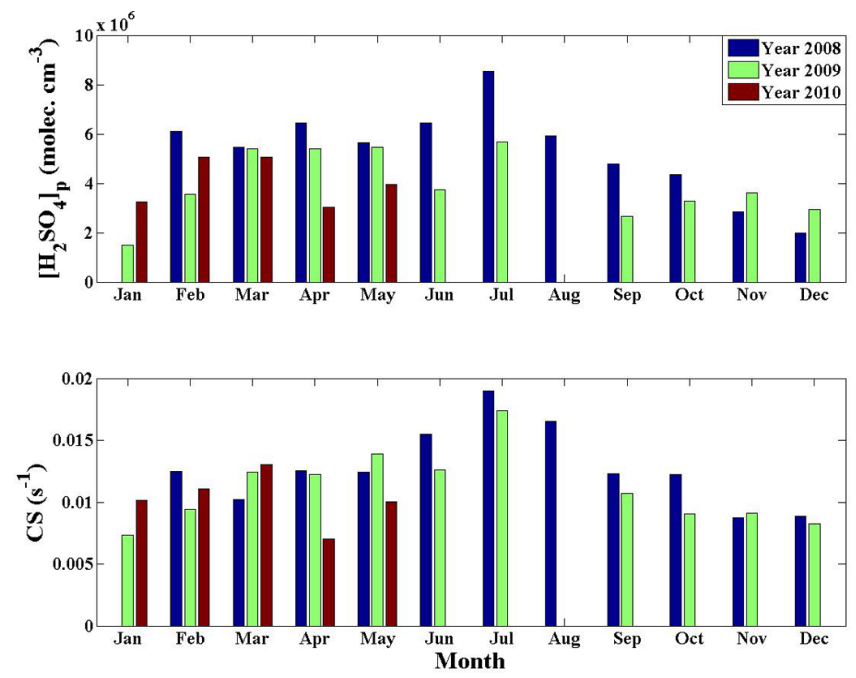

Fig. 7. Annual cycle of monthly medians of $\left[\mathrm{H}_{2} \mathrm{SO}_{4}\right]_{p}$ and condensation sink. The figure includes observations made during February-December 2008, January-July 2009, SeptemberDecember 2009, and January-May 2010.

Evening concentration peaks (Fig. 5) are usually more pronounced due to the need for space heating. The morning residential combustion period is usually curtailed due to warming temperatures and residents leaving for work. During the wet periods, which correspond to summer and the wetter autumn and spring months, domestic heating probably plays a smaller role as a particle source. Hence the observed Aitken and accumulation mode particles concentrations were higher in the dry periods (Fig. 4).

In contrast, the midday peak in particle concentrations is expected to be due to particle formation as a result of industrial and natural emissions, as will be explained in Sect. 5.2. The South African Highveld is well known for the formation of several well developed inversion layers, at different heights, that typically form during the night and persist until later morning (Garstang et al., 1996; Tyson et al., 1996; Wenig et al., 2003). High stack industry emissions can therefore accumulate between two inversion layers during nighttime, which is then released after the break-up of the inversion layers in the morning, hence resulting in a release of pollution at ground level. It is known that the PGM industry in this area has relatively high $\mathrm{SO}_{2}$ emissions, since this industry utilises sulphite ore (Xiao and Laplante, 2004) that generate substantial $\mathrm{SO}_{2}$ emissions. Thus, based on our observations we have identified two particle sources: $\mathrm{SO}_{2}$-based nucleation before or at midday and domestic burning during the morning and evening.

\subsection{Frequency of new particle formation days}

In this section particle nucleation event classification was done on the entire, un-cleaned ion (AIS) and particle (DMPS) datasets. This was done, since the procedure is visual and distinction between particle nucleation, undefined and nonevents can be done even if the distributions may be disturbed or broadened (Sect. 4.1). This decision allowed us to use as much data as possible and to obtain the most representative result.

The nucleation events were observed on $86 \%$ (DMPS), $84 \%$ (negative ions) and $78 \%$ (positive ions) of the analysed days at Marikana (Table 3, Fig. 9). With the ion spectrometer we were able to follow the growth of freshly nucleated ions, which allowed us to identify local charged particle formation events. The growing ion mode, however, was often visible from $3-7 \mathrm{~nm}$ upwards, which is an indication of a small contribution of ions to particle formation, or particle formation in residual layer or regional scale. If these observations were due to dominance of electrically neutral pathways in nucleation, then this would be in agreement with the theory and earlier observations that ion-mediated particle formation requires an environment of low nucleation rates, low temperature and aerosol content, but preferably having high concentrations of small ions and being rich with sulphuric acid (e.g. Laakso et al., 2002; Curtius et al., 2006; Iida, 2006; Yu, 2010). Despite the relatively high estimate of sulphuric acid concentration, none of these requirements were met at Marikana. It is also possible that the nucleation already began in a residual layer before mixing into the boundary layer or some horizontal distance before the measurement site. Therefore, we suggest that regional new particle formation was significant at Marikana, despite the strong local pollution sources. This is understandable, as the typical transport time above the western BIC area is short (1-2 $\mathrm{h}$ maximum).

At Marikana, the frequency of nucleation event days was higher than is reported from any other location (e.g. Kulmala et al., 2004; Jaatinen et al., 2009; Hirsikko et al., 2011). As an example, in the South African savannah, the monthly nucleation event day frequency was 55-90\% (Vakkari et al., 2011), and in the Australian Eucalyptus forest the corresponding frequency was ca. $52 \%$ (Suni et al., 2008). In contrast, in the clean rural boreal environment annual nucleation event day frequency is typically less than $30 \%$ (e.g. Dal Maso et al., 2005, 2007; Hirsikko et al., 2007a; Asmi et al., 2011). Over the polar areas the nucleation event day frequency is even lower (e.g. Virkkula et al., 2007; Asmi et al., 2010).

Typically, particle formation events at Marikana began earlier in the morning during the wet period than during the dry period, due to the earlier sunrise (Fig. 5). Although the difference of nucleation event day frequency between the various months was small, we may conclude that the DMPS nucleation event day frequency was slightly higher in summer and early autumn (wetter period) than in winter and spring (dryer period). In summer, the air was cleaner, but the estimated sulphuric acid concentration showed lower monthly median values (Fig. 7). In contrast, based on the ion spectrometer the nucleation event day frequency was slightly higher 
Table 2. Here Pearson correlation coefficients $(r)$ between various trace parameters and particle concentrations are presented. Particle number concentrations were calculated for four size ranges: $12-20 \mathrm{~nm}, 20-50 \mathrm{~nm}, 50-100 \mathrm{~nm}$ and $100-840 \mathrm{~nm}$.

\begin{tabular}{|c|c|c|c|c|}
\hline Dry | Wet season & Conc. $12-20 \mathrm{~nm}$ & Conc. $20-50 \mathrm{~nm}$ & Conc. $50-100 \mathrm{~nm}$ & Conc. $100-840 \mathrm{~nm}$ \\
\hline \multirow{2}{*}{$\begin{array}{l}\mathrm{SO}_{2} \text { : daytime } \\
\text { night-time }\end{array}$} & $0.48 \mid 0.49$ & $0.38 \mid 0.51$ & $0.18 \mid 0.36$ & $0.29 \mid 0.30$ \\
\hline & $-0.05 \mid-0.02$ & $0.10 \mid 0.09$ & $0.21 \mid 0.14$ & $0.30 \mid 0.12$ \\
\hline \multirow{2}{*}{$\begin{array}{l}\text { CO: daytime } \\
\text { night-time }\end{array}$} & $-0.13 \mid-0.02$ & $0.04 \mid-0.03$ & $0.44 \mid 0.09$ & $0.69 \mid 0.41$ \\
\hline & $0.14 \mid 0.35$ & $0.65 \mid 0.51$ & $0.76 \mid 0.58$ & $0.82 \mid 0.67$ \\
\hline \multirow{2}{*}{$\begin{array}{l}\mathrm{NO}_{\mathrm{x}} \text { : daytime } \\
\text { night-time }\end{array}$} & $-0.08 \mid 0.00$ & $0.07 \mid-0.01$ & $0.38 \mid 0.09$ & $0.47 \mid 0.32$ \\
\hline & $0.26 \mid 0.47$ & $0.53 \mid 0.53$ & $0.53 \mid 0.46$ & $0.55 \mid 0.43$ \\
\hline \multirow{2}{*}{$\begin{array}{l}\text { BC: daytime } \\
\text { night-time }\end{array}$} & $-0.08 \mid 0.02$ & $0.08 \mid-0.01$ & $0.41 \mid 0.09$ & $0.68 \mid 0.45$ \\
\hline & $0.07 \mid 0.35$ & $0.57 \mid 0.51$ & $0.72 \mid 0.58$ & $0.84 \mid 0.67$ \\
\hline \multirow{2}{*}{$\begin{array}{l}\text { CS: daytime } \\
\text { night-time }\end{array}$} & $0.02 \mid 0.15$ & $0.30 \mid 0.40$ & $0.74 \mid 0.72$ & $0.96 \mid 0.86$ \\
\hline & $0.00 \mid 0.12$ & $0.68 \mid 0.46$ & $0.91 \mid 0.85$ & $0.99 \mid 0.97$ \\
\hline
\end{tabular}
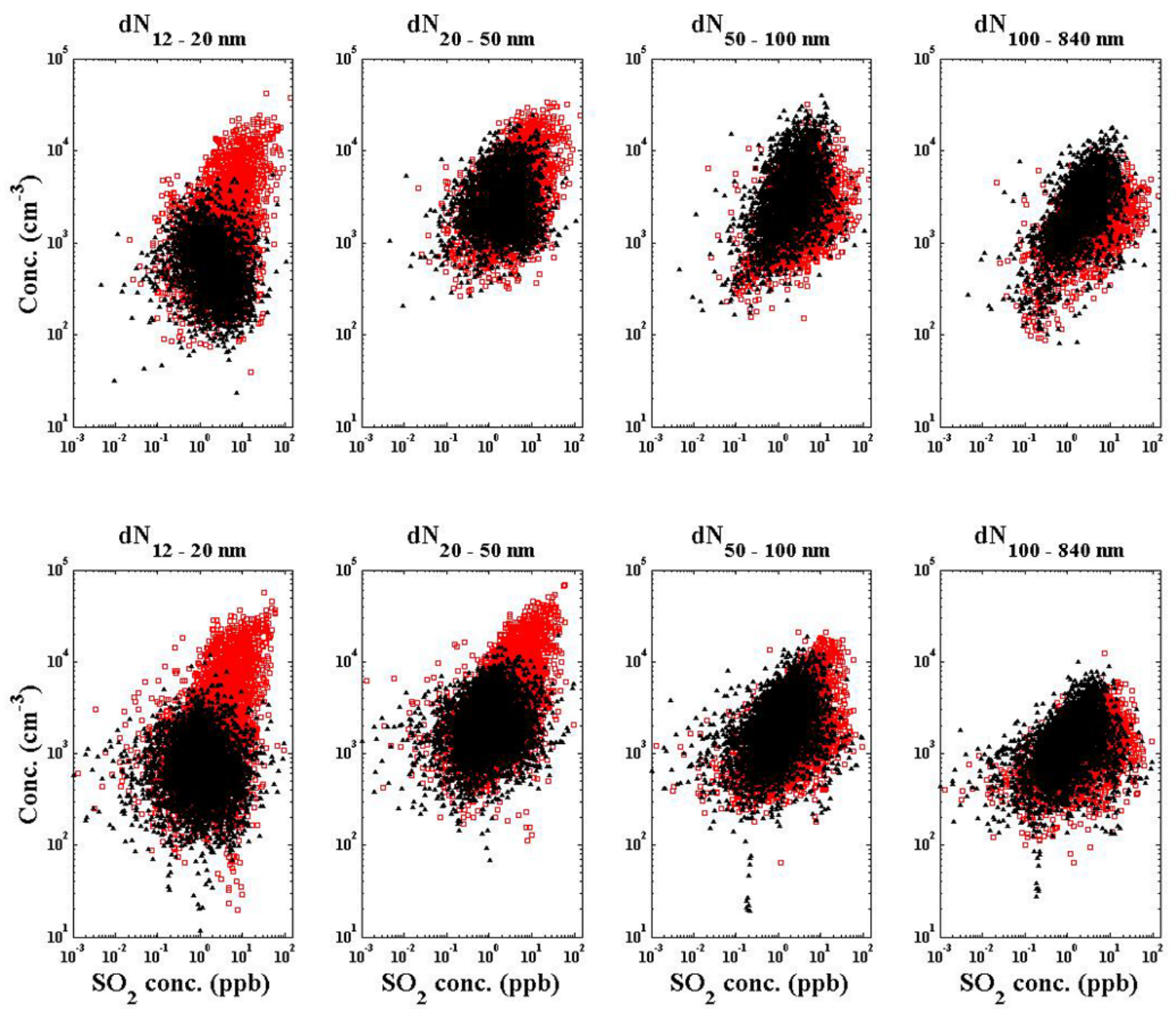

Fig. 8. Number concentrations of nucleation $\left(\mathrm{d} N_{12-20 \mathrm{~nm}}\right)$, Aitken $\left(\mathrm{d} N_{20-50 \mathrm{~nm}}\right.$ and $\left.\mathrm{d} N_{50-100 \mathrm{~nm}}\right)$ and accumulation $\left(\mathrm{d} N_{100-840 \mathrm{~nm}}\right)$ mode particles are presented as a function of $\mathrm{SO}_{2}$ concentration during the dry season (upper panel) and the wet season (lower panel). Red dots indicate daytime concentrations (between 06:30-17:30) and black dots represent night-time (between 18:30-05:30) concentrations. 
Table 3. Statistics of nucleation event day classification based on the DMPS and the AIS data.

\begin{tabular}{lcccc}
\hline & Analysed & Events & Non-events & Undefined \\
\hline DMPS & & & & \\
\hline Number of days & 649 & 559 & 2 & 88 \\
Fraction of analysed days (\%) & 100 & 86.1 & 0.3 & 13.6 \\
\hline AIS(-) & & & & \\
\hline Number of days & 606 & 509 & 9 & 88 \\
Fraction of analysed days (\%) & 100 & 84.0 & 1.5 & 14.5 \\
\hline AIS(+) & & & & 18 \\
Number of days & 606 & 476 & 18 & 12 \\
\hline Fraction of analysed days (\%) & 100 & 78.5 & 3.0 & 18.5 \\
\hline
\end{tabular}
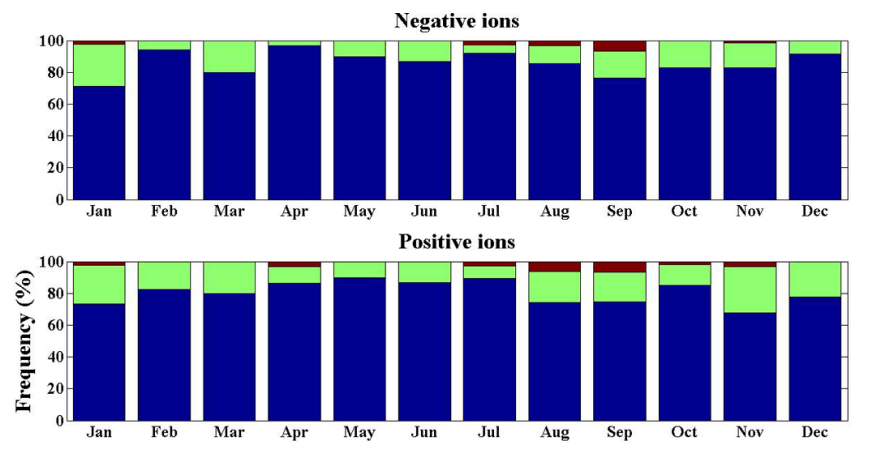
DMPS

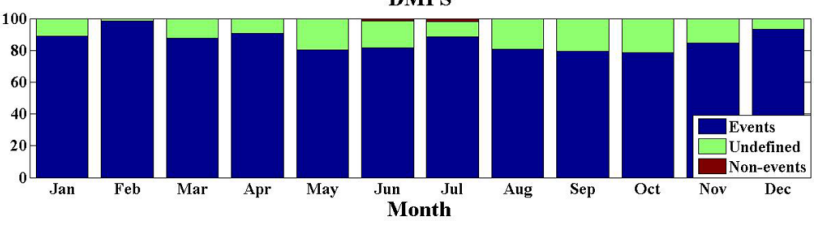

Fig. 9. Monthly distribution of particle formation, undefined and non-event days based on the DMPS (lower panel), positive (middle panel) and negative (upper panel) ion data (AIS).

during late autumn and winter having a similar annual cycle as $\left[\mathrm{H}_{2} \mathrm{SO}_{4}\right]_{p}$ (Fig. 7). Nevertheless, as shown in Table 1, concentrations of $\mathrm{SO}_{2},\left[\mathrm{H}_{2} \mathrm{SO}_{4}\right]_{p}$ and $\mathrm{CS}$ were typical for urban environments, but also higher during nucleation and growth events compared to undefined and non-event days, or to values observed in rural environments (e.g. Hirsikko et al., 2007b; Petäjä et al., 2009; Asmi et al., 2011; Wu et al., 2011; Mikkonen et al., 2011).

Air mass back trajectory analysis showed that despite the origin of the air masses, every trajectory circulated over the industrialised area of the western BIC and large cities nearby. The possible accumulation of trace gases from regional sources (Venter et al., 2012) may result in the observed high particle formation day frequency. Particle formation is also controlled by solar radiation. As is shown in Table 1, the non-event days were likely influenced by presence of optically thick clouds.

Despite the slightly lower frequency of positive ion events we cannot conclude with any certainty a clear polarity difference based on the visual classification (Table 3, Fig. 9). In contrast, in rural boreal environment negative ion events have been observed to be more frequent and stronger compared to positive ion events (Hirsikko et al., 2007a).

A very notable observation was that multiple consecutive nucleation events (i.e. more than one event per day), starting from the nano-meter sizes (ca. $1.5-3 \mathrm{~nm}$ ) followed by subsequent growth, were observed on ca. 100 days. All of these multiple events were observed during daylight. In addition to daytime nucleation, nocturnal nucleation events (Junninen et al., 2008; Lehtipalo et al., 2011), which were suppressed before diameter of ca. $3 \mathrm{~nm}$, were also observed at Marikana.

Svenningsson et al. (2008) have also observed several nucleation events, characterised by very fast growth rates, to occur during a day over wetland in a clean Sub-Arctic Abisko, where the nucleation event day frequency was $40 \%$ between spring and autumn. Svennigsson et al. (2008) observed such consecutive nucleation events related to homogeneous air masses to occur also during night-time in summer. However, they were not able to explain their observations of the nighttime or multiple events. Further investigations of the mechanisms behind these observations are required in the future.

\subsection{Particle formation and growth rates}

Particle formation and growth rates $\left(J_{12}\right.$ and $\left.\mathrm{GR}_{12-30}\right)$ were higher from spring to autumn (Fig. 10, also compare to Fig. 5). Thus, ambient conditions were less favourable for $12-30 \mathrm{~nm}$ particle formation and subsequent growth in winter (Tables 1 and 4). Magnitudes of formation and growth rates could not be explained by the estimated sulphuric acid concentration which indicates a substantial contribution from other vapours in these processes. We suggest that vapours of organic origin are probable candidates. The local wind 

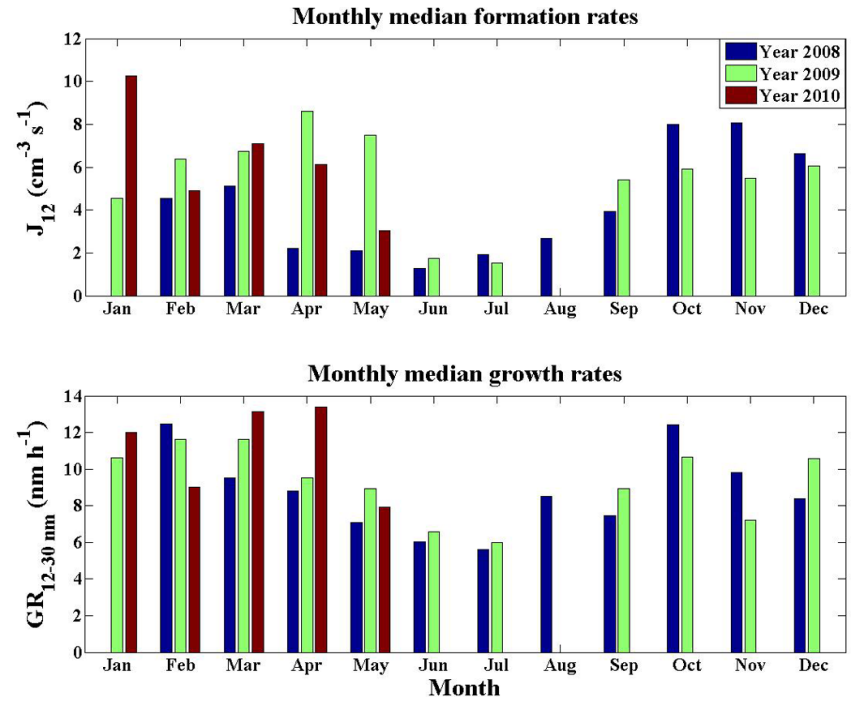

Fig. 10. Monthly median formation rates of $12-30 \mathrm{~nm}$ particles $\left(J_{12}\right)$ and growth rates $\left(\mathrm{GR}_{12-30 \mathrm{~nm}}\right)$ based on the DMPS data. The figure includes observations made during FebruaryDecember 2008, January-July 2009, September-December 2009, and January-May 2010.

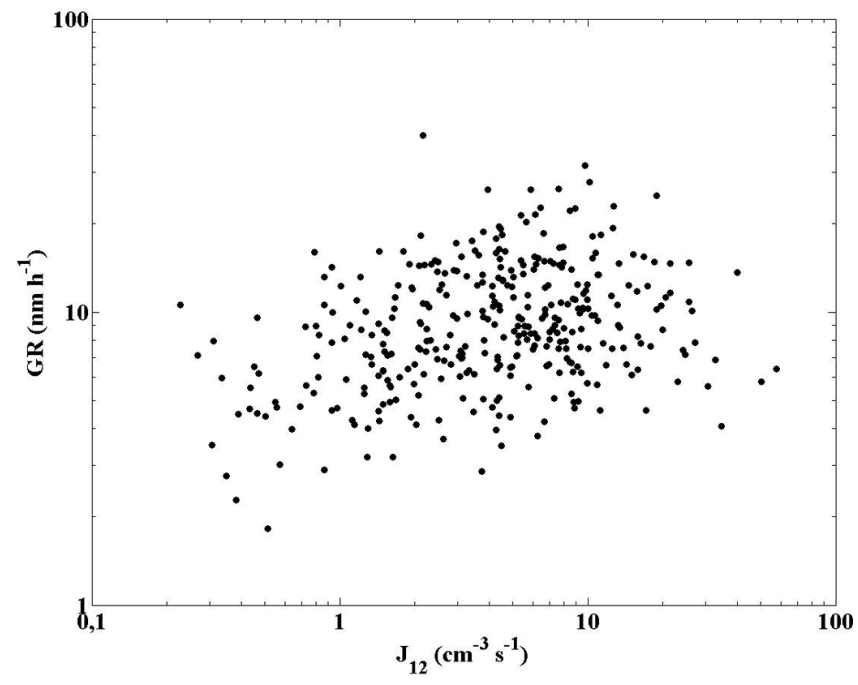

Fig. 11. Formation rate of $12 \mathrm{~nm}$ particles as a function of growth rate $(12-30 \mathrm{~nm})$ based on the DMPS data.

direction did not seem to enhance formation or growth rates. This was expected, since the above discussed analysis indicated that particle formation and growth is probably affected by accumulation of trace gas species (e.g. $\mathrm{SO}_{2}$ and organics) from regional sources.

High formation rates were observed to occur simultaneously with fast growth rates (Fig. 11). Both formation and growth rates were observed to correlate with concentrations of Aitken mode particles during nucleation events, but not with the accumulation mode particle concentrations. When
Table 4. Mean, median, standard deviation, and 10th/90th percentiles of growth rate $(\mathrm{GR})$ and formation rate $\left(J_{12}\right)$ separately for dry and wet periods based on the DMPS. The growth rates based on the AIS data were calculated separately for the positive and the negative polarity.

Mean \pm std $\quad$ Median $\begin{aligned} & 10 \text { th } \mid 90 \text { th } \\ & \text { percentile }\end{aligned}$

\begin{tabular}{llll}
\hline $\begin{array}{l}\text { Dry period } \\
\text { DMPS }\end{array}$ & & \\
\hline$J_{12}\left(\mathrm{~cm}^{-3} \mathrm{~s}^{-1}\right)$ & $4.5 \pm 6.1$ & 2.5 & $0.6 \mid 10.7$ \\
$\mathrm{GR}_{12-30 \mathrm{~nm}}\left(\mathrm{~nm} \mathrm{~h}^{-1}\right)$ & $8.0 \pm 4.1$ & 7.1 & $4.2 \mid 13.1$ \\
\hline $\mathrm{AIS}(+)$ & & & \\
\hline $\mathrm{GR}_{3-7 \mathrm{~nm}}\left(\mathrm{~nm} \mathrm{~h}^{-1}\right)$ & $12.5 \pm 8.2$ & 10.5 & $4.7 \mid 24.5$ \\
$\mathrm{GR}_{7-12 \mathrm{~nm}}\left(\mathrm{~nm} \mathrm{~h}^{-1}\right)$ & $19.0 \pm 11.3$ & 16.0 & $7.0 \mid 38.3$ \\
\hline $\mathrm{AIS}(-)$ & & & \\
\hline $\mathrm{GR}_{3-7 \mathrm{~nm}}\left(\mathrm{~nm} \mathrm{~h}^{-1}\right)$ & $11.9 \pm 7.3$ & 10.1 & $4.7 \mid 22.6$ \\
$\mathrm{GR}_{7-12 \mathrm{~nm}}\left(\mathrm{~nm} \mathrm{~h}^{-1}\right)$ & $19.7 \pm 10.5$ & 17.5 & $8.2 \mid 34.5$
\end{tabular}

Wet period

DMPS

\begin{tabular}{llll}
\hline$J_{12}\left(\mathrm{~cm}^{-3} \mathrm{~s}^{-1}\right)$ & $7.6 \pm 7.3$ & 5.7 & $1.5 \mid 16.4$ \\
$\mathrm{GR}_{12-30 \mathrm{~nm}\left(\mathrm{~nm} \mathrm{~h}^{-1}\right)}$ & $11.1 \pm 5.2$ & 10.2 & $5.8 \mid 16.2$ \\
\hline $\mathrm{AIS}(+)$ & & & \\
\hline $\mathrm{GR}_{3-7 \mathrm{~nm}\left(\mathrm{~nm} \mathrm{~h}^{-1}\right)}$ & $13.1 \pm 7.7$ & 11.1 & $5.4 \mid 24.2$ \\
$\mathrm{GR}_{7-12 \mathrm{~nm}\left(\mathrm{~nm} \mathrm{~h}^{-1}\right)} 19.1 \pm 11.0$ & 15.4 & $7.9 \mid 35.4$ \\
\hline $\mathrm{AIS}(-)$ & & & \\
\hline $\mathrm{GR}_{3-7 \mathrm{~nm}\left(\mathrm{~nm} \mathrm{~h}^{-1}\right)} 13.3 \pm 7.4$ & 11.3 & $5.5 \mid 23.7$ \\
$\mathrm{GR}_{7-12 \mathrm{~nm}}\left(\mathrm{~nm} \mathrm{~h}^{-1}\right)$ & $17.3 \pm 8.8$ & 15.7 & $7.6 \mid 29.9$ \\
\hline
\end{tabular}

comparing our results of $J_{12}$ and $\mathrm{GR}_{12-30}$ (Fig. 10) to observations by Vakkari et al. (2011) in the semi-clean South African savannah, we notice that both the magnitude and temporal variation of these parameters were similar.

Even though sub- $3 \mathrm{~nm}$ ion data was acceptable during $14 \%$ of the time, we were able to estimate growth rates of sub- $3 \mathrm{~nm}$ ions only on 13 days. Growth rate analysis for $7-$ $20 \mathrm{~nm}$ ions was possible only during half of the months due to data quality issues. Sub-20 nm charged particle growth rates in all size ranges were slightly higher during months from autumn to late spring (Figs. 12 and 13, Table 4). Growth rates of charged particles were also compared to Aitken and accumulation mode particle concentrations during the nucleation events. The analysis showed that the faster growth rates were observed when Aitken mode particle concentrations were higher.

The magnitude of presented formation and growth rates is in accordance with earlier observations in urban and polluted environments (Kulmala et al., 2004 and references therein). The observed formation (up to $100 \mathrm{~cm}^{-3} \mathrm{~s}^{-1}$ ) and growth 

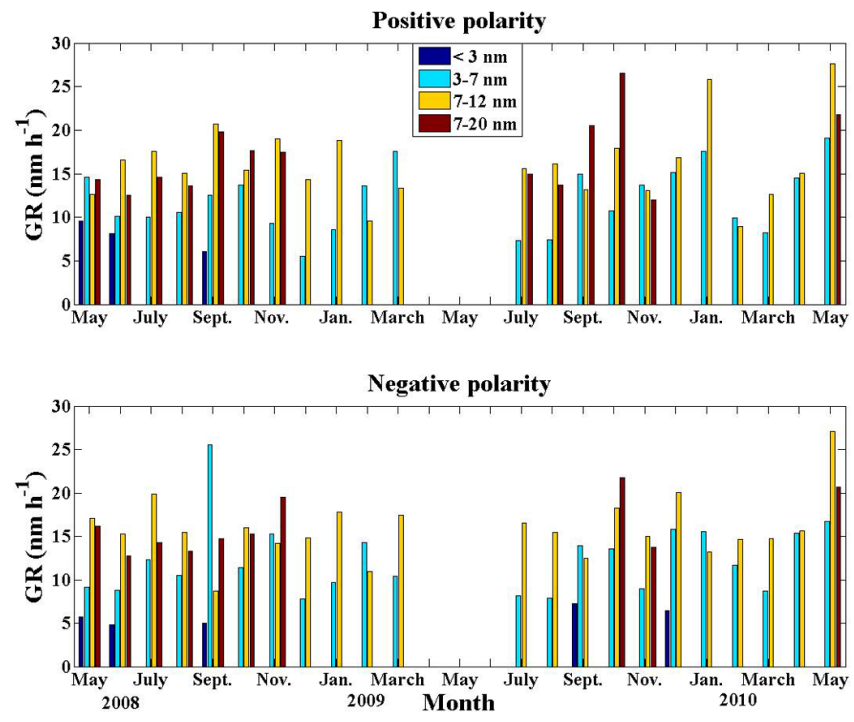

Fig. 12. Monthly median growth rates of positive and negative ions (based on the AIS data) for different size fractions indicated with different colours.

rates are typically higher in polluted environments compared to rural or polar sites (e.g. Kulmala et al., 2004; Dal Maso et al., 2005, 2007; Iida et al., 2008; Jaatinen et al., 2009; Kalafut-Pettibone et al., 2011), due to more pronounced concentrations of $\mathrm{H}_{2} \mathrm{SO}_{4}$ vapour and stronger competition between growth and coagulation loss. Earlier observations suggest that high growth rate and CS exist at the same time since slow growth cannot be observed due to quick scavenging by pre-existing aerosol (e.g. Kulmala et al., 2005). The CS in Marikana was 3-5 times higher than in rural Botsalano (Vakkari et al., 2011), which may balance the potentially increased particle growth rates.

\section{Concluding remarks}

The aim of this work was to characterise particle sources and formation events at a residential area surrounded by mining and pyrometallurgical smelting industries in South Africa. The aerosol particle number concentrations were quite high (on average $10^{4} \mathrm{~cm}^{-3}$ ) and typical for urban or industrial environments, although, higher particle number concentrations have also been reported in literature (e.g. Ruuskanen et al., 2001; Woo et al., 2001; Wehner and Wiedensohler, 2003; Hussein et al., 2004; Stanier et al., 2004; Mönkkönen et al., 2005; Wu et al., 2008; Cheung et al., 2011). Our results, together with the analysis by Venter et al. (2012) indicate that the major source for nucleation mode particles was new particle formation (most likely $\mathrm{SO}_{2}$-based) around midday. Aitken and accumulation mode particles originated from domestic burning for heating and cooking, but in the afternoon an increased Aitken mode particle concentrations were also

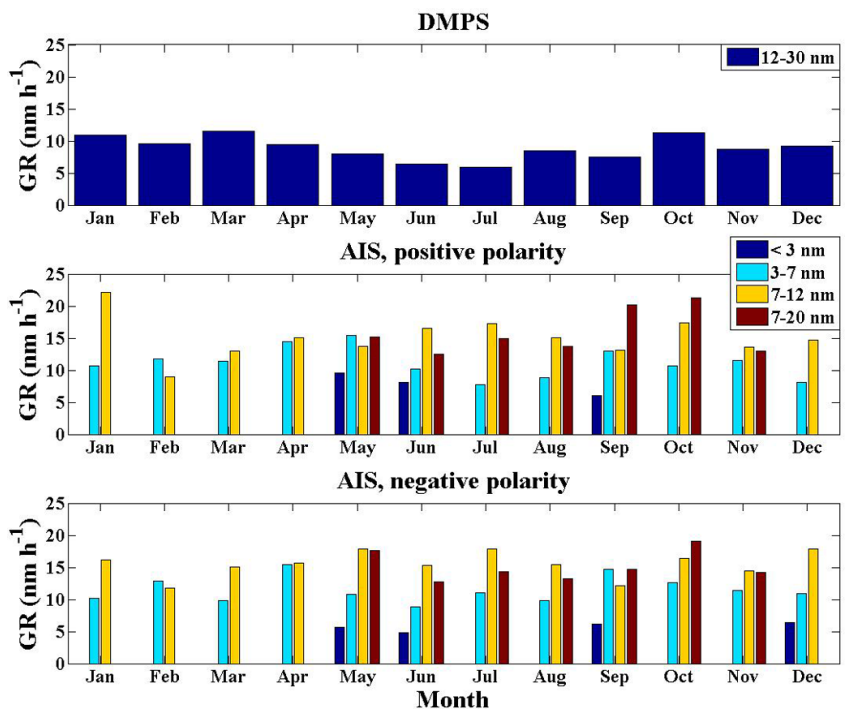

Fig. 13. Annual monthly median growth rates (GR) based on DMPS (upper panel), positive (middle panel) and negative (lower panel) ion data (AIS).

observed due to regional nucleation and subsequent growth from industrial, residential and biological emissions.

Nucleation event day frequency was very high, i.e. $86 \%$ of the analysed days, which is the highest thus far recorded in any environment (e.g. Kulmala et al., 2004; Hirsikko et al., 2011). Both the local sources and regional conditions affected the particle formation and growth. The formation and growth rates were high and typical for urban environments (Kulmala et al., 2004; Dal Maso et al., 2005, 2007; Iida et al., 2008; Jaatinen et al., 2009). However, the temporal cycle of the new particle formation characteristics was similar as have been observed by Vakkari et al. (2011) over a semiclean savannah in South Africa.

From the results presented it is clear that, despite the industrial and residential activities in the western BIC are sources of particulates, a large fraction of particle number concentration is due to regional nucleation. Our results combined with the results of Venter et al. (2012) provide valuable information for the assessment of local air quality and the possible health threat to the community in the western BIC, as well as supply information for decision making processes in the future for limiting air pollution. The results presented here were the most thorough analysis of particle formation and growth in an informal and semi-formal residential area, influenced by mining and pyrometallurgical industries.

Acknowledgements. We would like to express our appreciation for Tshepo Lenake, Rustenburg Municipality, and Finnish Academy (project no 117505: Air pollution in Southern Africa 2007-09; no 132640: Atmospheric monitoring capacity building in Southern Africa 2010-12), as well as support from the North-West University.The financial support by the Academy of Finland Centre 
of Excellence program (project no 1118615) is also gratefully acknowledged.

Edited by: L. M. Russell

\section{References}

Air Resources Laboratory: Gridded Meteorological Data Archives, available at: http://www.arl.noaa.gov/archives.php, 2011.

Asmi, E., Frey, A., Virkkula, A., Ehn, M., Manninen, H. E., Timonen, H., Tolonen-Kivimäki, O., Aurela, M., Hillamo, R., and Kulmala, M.: Hygroscopicity and chemical composition of Antarctic sub-micrometre aerosol particles and observations of new particle formation, Atmos. Chem. Phys., 10, 4253-4271, doi:10.5194/acp-10-4253-2010, 2010.

Asmi, E., Kivekäs, N., Kerminen, V.-M., Komppula, M., Hyvärinen, A.-P., Hatakka, J., Viisanen, Y., and Lihavainen, H.: Secondary new particle formation in Northern Finland Pallas site between the years 2000 and 2010, Atmos. Chem. Phys., 11, 12959-12972, doi:10.5194/acp-11-12959-2011, 2011.

Beukes, J. P., Dawson, N. F., and Van Zyl, P. G.: Theoretical and practical aspects of $\mathrm{Cr}(\mathrm{VI})$ in the South African FeCr industry, S. African Inst. Min. M., 110, 743-750, 2010.

Breitner, S., Liu, L., Cyrys, J., Brüske, I., Franck, U., Schlink, U., Leitte, A.M., Herbath, O., Wiedensohler, A., Wehner, B., Hu, M., Pan, X.-C., Wichmann, H.-E., and Peters, A.: Sub-micrometer particulate air ion pollution and cardiovascular mortality in Beijing, China, Sci. Total Environ., 409, 5196-5204, 2011.

Brus, D., Neitola, K., Hyvärinen, A.-P., Petäjä, T., Vanhanen, J., Sipilä, M., Paasonen, P., Kulmala, M., and Lihavainen, H.: Homogenous nucleation of sulfuric acid and water at close to atmospherically relevant conditions, Atmos. Chem. Phys., 11, 52775287, doi:10.5194/acp-11-5277-2011, 2011.

Cheung, H. C., Morawska, L., and Ristovski, Z. D.: Observation of new particle formation in subtropical urban environment, Atmos. Chem. Phys., 11, 3823-3833, doi:10.5194/acp-11-38232011, 2011.

Curtius, J., Lovejoy, E. R., and Froyd, K. D.: Atmospheric ion induced aerosol nucleation, Space Sci. Rev., 125, 159-167, 2006.

Cramer, L. A., Basson, J., and Nelson, L. R.: The impact of platinum production from UG2 ore on ferrochrome production in South African, S. African Inst. Min. M., 104, 517-527, 2004.

Dal Maso, M., Kulmala, M., Riipinen, I., Wagner, R., Hussein, T., Aalto, P. P., and Lehtinen, K. E. J.: Formation and growth of fresh atmospheric aerosols: eight years of aerosol size distribution data from SMEAR II, Hyytiälä, Finland, Boreal Environ. Res., 10, 323-336, 2005.

Dal Maso, M., Sogacheva, L., Aalto, P.P., Riipinen, I., Komppula, M., Tunved, P., Korhonen, L., Suur-Uski, V., Hirsikko, A., Kurtén, T., Kerminen, V.-M., Lihavainen, H., Viisanen, Y., Hansson, H.-C., and Kulmala, M.: Aerosol size distribution measurements at four Nordic field stations: identification, analysis, and trajectory analysis of new particle formation bursts, Tellus, 59B, 350-361, 2007.

Draxler, R. R. and Hess, G. D.: Description of the HYSPLIT 4 Modelling System, NOAA Technical Memorandum ERL ARL-224, 2004.

Dunn, M. J., Jiménez, J.-L., Baumgardner, D., Castro, T., McMurry, P. H., and Smith, J. N.: Measurements of Mexico
City nanoparticle size distributions: Observations of new particle formation and growth, Geophys. Res. Lett., 31, L01012, doi:10.1029/2004GL019483, 2004.

Fiedler, V., Dal Maso, M., Boy, M., Aufmhoff, H., Hoffmann, J., Schuck, T., Birmili, W., Hanke, M., Uecker, J., Arnold, F., and Kulmala, M.: The contribution of sulphuric acid to atmospheric particle formation and growth: a comparison between boundary layers in Northern and Central Europe, Atmos. Chem. Phys., 5, 1773-1785, doi:10.5194/acp-5-1773-2005, 2005.

Gagné, S., Lehtipalo, K., Manninen, H. E., Nieminen, T., Schobesberger, S., Franchin, A., Yli-Juuti, T., Boulon, J., Sonntag, A., Mirme, S., Mirme, A., Hõrrak, U., Petäjä, T., Asmi, E., and Kulmala, M.: Intercomparison of air ion spectrometers: an evaluation of results in varying conditions, Atmos. Meas. Tech., 4, 805-822, doi:10.5194/amt-4-805-2011, 2011.

Garstang, M., Tyson, P. D., Swap, R., Edwards, M., Kållberg, P., and Lindesay, J. A.: Horizontal and vertical transport of air over southern Africa, J. Geophys. Res., 101, 721-736, 1996.

Hand, J. L. and Malm, W. C.: Review of aerosol mass scattering efficiencies from ground-based measurements since 1990, J. Geophys. Res., 112, D16203, doi:10.1029/2007JD008484, 2007.

Hirsikko, A., Laakso, L., Hõrrak, U., Aalto, P., Kerminen, V., and Kulmala, M.: Annual and size dependent variation of growth rates and ion concentrations in boreal forest, Boreal Environ. Res., 10, 357-369, 2005.

Hirsikko, A., Bergman, T., Laakso, L., Dal Maso, M., Riipinen, I., Hõrrak, U., and Kulmala, M.: Identification and classification of the formation of intermediate ions measured in boreal forest, Atmos. Chem. Phys., 7, 201-210, doi:10.5194/acp-7-201-2007, 2007a.

Hirsikko, A., Yli-Juuti, T., Nieminen, T., Vartiainen, E., laakso, L., Hussein, T., and Kulmala: Indoor and outdoor air ions and aerosol particles in the uban atmosphere of Helsinki: characteristics, sources and formation, Boreal Eviron. Res., 12, 295-310, $2007 b$.

Hirsikko, A., Nieminen, T., Gagné, S., Lehtipalo, K., Manninen, H. E., Ehn, M., Hõrrak, U., Kerminen, V.-M., Laakso, L., McMurry, P. H., Mirme, A., Mirme, S., Petäjä, T., Tammet, H., Vakkari, V., Vana, M., and Kulmala, M.: Atmospheric ions and nucleation: a review of observations, Atmos. Chem. Phys., 11, 767798, doi:10.5194/acp-11-767-2011, 2011.

Hoppel, W. A.: Determination of the aerosol size distribution from the mobility distribution of the charged fraction of aerosols, J. Aerosol Sci., 9, 41-54, 1978.

Hussein, T., Puustinen, A., Aalto, P. P., Mäkelä, J. M., Hämeri, K., and Kulmala, M.: Urban aerosol number size distributions, Atmos. Chem. Phys., 4, 391-411, doi:10.5194/acp-4-391-2004, 2004.

Hussein, T., Dal Maso, M., Petäjä, T., Koponen, I. K., Paatero, P., Aalto, P. P., Hämeri, K., and Kulmala, M.: Evaluation of an automatic algorithm for fitting the particle number size distributions, Boreal Environ. Res., 10, 337-355, 2005.

Iida, K., Stolzenburg, M., McMurry, P., Dunn, M. J., Smith, J. N., Eisele, F., and Keady, P.: Contribution of ion-induced nucleation to new particle formation: Methodology and its application to atmospheric observations in Boulder, Colorado, J. Geophys. Res., 111, D23201, doi:10.1029/2006JD007167, 2006.

Iida, K., Stolzenburg, M. R., McMurry, P. H., and Smith, J. N.: Estimating nanoparticle growth rates from size-dependent 
charged fractions: Analysis of new particle formation events in Mexico City, J. Geophys. Res., 113, D05207, doi:10.1029/2007JD009260, 2008.

IPCC: Fourth Assessment Report of the Intergovernmental Panel on Climate Change (IPCC), 2007.

Jaatinen, A., Hamed, A., Joutsensaari, J., Mikkonen, S., Birmili, W., Wehner, B., Spindler, G., Wiedensohler, A., Decasari, S., Mircea, M., Facchini, M. C., Junninen, H., Kulmala, M., Lehtinen, K. E. J., and Laaksonen, A.: A comparison of new particle formation events in the boundary layer at three different sites in Europe, Boreal Environ. Res., 14, 481-498, 2009.

Jayaratne, E. R. and Verma, T. S.: The impact of biomass burning on the environmental aerosol concentration in Gaborone, Botswana, Atmos. Environ., 35, 1821-1828, 2001.

Jokinen, V. and Mäkelä, J. M.: Closed loop arrangement with critical orifice for DMA sheath/excess flow system, J. Aerosol Sci., 28, 643-648, 1997.

Junninen, H., Hulkkonen, M., Riipinen, I., Nieminen, T., Hirsikko, A., Suni, T., Boy, M., Lee, S.-H., Vana, M., Tammet, H., Kerminen, V.-M., and Kulmala, M.: Observations on nocturnal growth of atmospheric clusters, Tellus, 60B, 365-371, 2008.

Kalafut-Pettibone, A. J., Wang, J., Eichinger, W. E., Clarke, A., Vay, S. A., Blake, D. R., and Stanier, C. O.: Size-resolved aerosol emission factors and new particle formation/growth activity occurring in Mexico City during the MILAGRO 2006 Campaign, Atmos. Chem. Phys., 11, 8861-8881, doi:10.5194/acp-11-88612011, 2011.

Kuang, C., McMurry, P. H., McCormick, A. V., and Eisele, F. L.: Dependence of nucleation rates on sulphuric acid vapor concentrations in diverse atmospheric locations, J. Geophys. Res., 113, D10209, doi:10.1029/2007JD009253, 2008.

Kulmala, M., Vehkamäki, H., Petäjä, T., Dal Maso, M., Lauri, A., Kerminen, V.-M., Birmili, W., and McMurry, P. H.: Formation and growth rates of ultrafine atmospheric particles: a review of observations, J. Aerosol Sci., 35, 143-176, 2004.

Kulmala, M., Petäjä, T., Mönkkönen, P., Koponen, I. K., Dal Maso, M., Aalto, P. P., Lehtinen, K. E. J., and Kerminen, V.-M.: On the growth of nucleation mode particles: source rates of condensable vapor in polluted and clean environments, Atmos. Chem. Phys., 5, 409-416, doi:10.5194/acp-5-409-2005, 2005.

Kulmala, M., Riipinen, I., Sipilä, M., Manninen, H. E., Petäjä, T., Junninen, H., Dal Maso, M., Mordas, G., Mirme, A., Vana, M., Hirsikko, A., Laakso, L., Harrison, R. M., Hanson, I., Leung, C., Lehtinen, K. E. J., and Kerminen, V.-M.: Toward direct measurement of atmospheric nucleation, Science, 318, 89-92, 2007.

Kulmala, M., Asmi, A., Lappalainen, H. K., Baltensperger, U., Brenguier, J.-L., Facchini, M. C., Hansson, H.-C., Hov, Ø., O'Dowd, C. D., Pöschl, U., Wiedensohler, A., Boers, R., Boucher, O., de Leeuw, G., Denier van der Gon, H. A. C., Feichter, J., Krejci, R., Laj, P., Lihavainen, H., Lohmann, U., McFiggans, G., Mentel, T., Pilinis, C., Riipinen, I., Schulz, M., Stohl, A., Swietlicki, E., Vignati, E., Alves, C., Amann, M., Ammann, M., Arabas, S., Artaxo, P., Baars, H., Beddows, D. C. S., Bergström, R., Beukes, J. P., Bilde, M., Burkhart, J. F., Canonaco, F., Clegg, S. L., Coe, H., Crumeyrolle, S., D’Anna, B., Decesari, S., Gilardoni, S., Fischer, M., Fjaeraa, A. M., Fountoukis, C., George, C., Gomes, L., Halloran, P., Hamburger, T., Harrison, R. M., Herrmann, H., Hoffmann, T., Hoose, C., Hu, M., Hyvärinen, A., Hõrrak, U., Iinuma, Y., Iversen, T., Josipovic,
M., Kanakidou, M., Kiendler-Scharr, A., Kirkevåg, A., Kiss, G., Klimont, Z., Kolmonen, P., Komppula, M., Kristjánsson, J.-E., Laakso, L., Laaksonen, A., Labonnote, L., Lanz, V. A., Lehtinen, K. E. J., Rizzo, L. V., Makkonen, R., Manninen, H. E., McMeeking, G., Merikanto, J., Minikin, A., Mirme, S., Morgan, W. T., Nemitz, E., O’Donnell, D., Panwar, T. S., Pawlowska, H., Petzold, A., Pienaar, J. J., Pio, C., Plass-Duelmer, C., Prévôt, A. S. H., Pryor, S., Reddington, C. L., Roberts, G., Rosenfeld, D., Schwarz, J., Seland, Ø., Sellegri, K., Shen, X. J., Shiraiwa, M., Siebert, H., Sierau, B., Simpson, D., Sun, J. Y., Topping, D., Tunved, P., Vaattovaara, P., Vakkari, V., Veefkind, J. P., Visschedijk, A., Vuollekoski, H., Vuolo, R., Wehner, B., Wildt, J., Woodward, S., Worsnop, D. R., van Zadelhoff, G.-J., Zardini, A. A., Zhang, K., van Zyl, P. G., Kerminen, V.-M., S Carslaw, K., and Pandis, S. N.: General overview: European Integrated project on Aerosol Cloud Climate and Air Quality interactions (EUCAARI) - integrating aerosol research from nano to global scales, Atmos. Chem. Phys., 11, 13061-13143, doi:10.5194/acp11-13061-2011, 2011.

Laakso, L., Mäkelä, J. M., Pirjola, L., and Kulmala, M.: Model studies on ion-induced nucleation in the atmosphere, J. Geophys. Res., 107, 4427, doi:10.1029/2002JD002140, 2002.

Laakso, L., Laakso, H., Aalto, P. P., Keronen, P., Petäjä, T., Nieminen, T., Pohja, T., Siivola, E., Kulmala, M., Kgabi, N., Molefe, M., Mabaso, D., Phalatse, D., Pienaar, K., and Kerminen, V.-M.: Basic characteristics of atmospheric particles, trace gases and meteorology in a relatively clean Southern African Savannah environment, Atmos. Chem. Phys., 8, 4823-4839, doi:10.5194/acp-8-4823-2008, 2008.

Lehtipalo, K., Sipilä, M., Junninen, H., Ehn, M., Brendt, T., Kajos, M. K., Worsnop, D. R., Petäjä, T., and Kulmala, M.: Observations of Nano-CN in the Nocturnal Boreal Forest, Aerosol Sci. Technol., 45, 499-509, 2011.

Leppä, J., Anttila, T., Kerminen, V.-M., Kulmala, M., and Lehtinen, K. E. J.: Atmospheric new particle formation: real and apparent growth of neutral and charged particles, Atmos. Chem. Phys., 11, 4939-4955, doi:10.5194/acp-11-4939-2011, 2011.

Lohmann, U. and Feichter, J.: Global indirect aerosol effects: a review, Atmos. Chem. Phys., 5, 715-737, doi:10.5194/acp-5-7152005, 2005

Manninen, H. E., Nieminen, T., Asmi, E., Gagné, S., Häkkinen, S., Lehtipalo, K., Aalto, P., Vana, M., Mirme, A., Mirme, S., Hõrrak, U., Plass-Dülmer, C., Stange, G., Kiss, G., Hoffer, A., Törő, N., Moerman, M., Henzing, B., de Leeuw, G., Brinkenberg, M., Kouvarakis, G. N., Bougiatioti, A., Mihalopoulos, N., O’Dowd, C., Ceburnis, D., Arneth, A., Svenningsson, B., Swietlicki, E., Tarozzi, L., Decesari, S., Facchini, M. C., Birmili, W., Sonntag, A., Wiedensohler, A., Boulon, J., Sellegri, K., Laj, P., Gysel, M., Bukowiecki, N., Weingartner, E., Wehrle, G., Laaksonen, A., Hamed, A., Joutsensaari, J., Petäjä, T., Kerminen, V.-M., and Kulmala, M.: EUCAARI ion spectrometer measurements at 12 European sites - analysis of new particle formation events, Atmos. Chem. Phys., 10, 7907-7927, doi:10.5194/acp-10-79072010, 2010.

Mertes, S., Schröder, F., and Wiedensohler, A.: The particle detection efficiency curve of the TSI-3010 CPC as a function of temperature difference between saturator and condenser, Aerosol Sci. Technol., 23, 257-261, 1995. 
Millikan, R. A.: The general law of fall of a small spherical body through a gas, and its bearing upon the nature of molecular reflection from surfaces, Phys. Rev., 22, 1-23, 1923.

Mikkonen, S., Romakkaniemi, S., Smith, J. N., Korhonen, H., Petäjä, T., Plass-Duelmer, C., Boy, M., McMurry, P. H., Lehtinen, K. E. J., Joutsensaari, J., Hamed, A., Mauldin III, R. L., Birmili, W., Spindler, G., Arnold, F., Kulmala, M., and Laaksonen, A.: A statistical proxy for sulphuric acid concentration, Atmos. Chem. Phys., 11, 11319-11334, doi:10.5194/acp-11-11319-2011, 2011.

Mirme, A., Tamm, E., Mordas, G., Vana, M., Uin, J., Mirme, S., Bernotas, T., Laakso, L., Hirsikko, A., and Kulmala, M.: A widerange multi-channel Air Ion Spectrometer, Boreal Environ. Res., 12, 247-264, 2007.

Myhre, G: Consistency between satellite-derived and modeled estimates of the direct aerosol effect, Science, 325, 187-190, 2009.

Mönkkönen, P., Uma, R., Srinivasan, D., Koponen, I. K., Lehtinen, K. E. J., Hämeri, K., Suresh, R., Sharma, V. P., and Kulmala, M.: Relationship and variation of aerosol number and $\mathrm{PM}_{10}$ mass concentrations in a highly polluted urban environment - New Delhi, India, Atmos. Environ., 38, 425-433, 2004.

Mönkkönen, P., Koponen, I. K., Lehtinen, K. E. J., Hämeri, K., Uma, R., and Kulmala, M.: Measurements in a highly polluted Asian mega city: observations of aerosol number size distribution, modal parameters and nucleation events, Atmos. Chem. Phys., 5, 57-66, doi:10.5194/acp-5-57-2005, 2005.

Paasonen, P., Nieminen, T., Asmi, E., Manninen, H. E., Petäjä, T., Plass-Dülmer, C., Flentje, H., Birmili, W., Wiedensohler, A., Hõrrak, U., Metzger, A., Hamed, A., Laaksonen, A., Facchini, M. C., Kerminen, V.-M., and Kulmala, M.: On the roles of sulphuric acid and low-volatility organic vapours in the initial steps of atmospheric new particle formation, Atmos. Chem. Phys., 10, 11223-11242, doi:10.5194/acp-10-11223-2010, 2010.

Petäjä, T., Mauldin, III, R. L., Kosciuch, E., McGrath, J., Nieminen, T., Paasonen, P., Boy, M., Adamov, A., Kotiaho, T., and Kulmala, M.: Sulfuric acid and $\mathrm{OH}$ concentrations in a boreal forest site, Atmos. Chem. Phys., 9, 7435-7448, doi:10.5194/acp9-7435-2009, 2009.

Pope, C. A. and Dockery, D. W.: Health effects of fine particulate air pollution: lines that connect, J. Air Waste Manage., 56, 709-742, 2006.

Quaas, J., Ming, Y., Menon, S., Takemura, T., Wang, M., Penner, J. E., Gettelman, A., Lohmann, U., Bellouin, N., Boucher, O., Sayer, A. M., Thomas, G. E., McComiskey, A., Feingold, G., Hoose, C., Kristjánsson, J. E., Liu, X., Balkanski, Y., Donner, L. J., Ginoux, P. A., Stier, P., Grandey, B., Feichter, J., Sednev, I., Bauer, S. E., Koch, D., Grainger, R. G., Kirkevåg, A., Iversen, T., Seland, Ø., Easter, R., Ghan, S. J., Rasch, P. J., Morrison, H., Lamarque, J.-F., Iacono, M. J., Kinne, S., and Schulz, M.: Aerosol indirect effects - general circulation model intercomparison and evaluation with satellite data, Atmos. Chem. Phys., 9, 8697-8717, doi:10.5194/acp-9-8697-2009, 2009.

Riipinen, I., Sihto, S.-L., Kulmala, M., Arnold, F., Dal Maso, M., Birmili, W., Saarnio, K., Teinilä, K., Kerminen, V.-M., Laaksonen, A., and Lehtinen, K. E. J.: Connections between atmospheric sulphuric acid and new particle formation during QUEST III-IV campaigns in Heidelberg and Hyytiälä, Atmos. Chem. Phys., 7, 1899-1914, doi:10.5194/acp-7-1899-2007, 2007.

Russell, A. G. and Brunekreef, B.: A focus on particulate matter and health, Environ. Sci. Technol., 43, 4620-4625, 2009.
Ruuskanen, J., Tuch, T., Ten Brink, H., Peters, A., Khlystov, A., Mirme, A., Kos, G. P. A., Brunekreef, B., Wichmann, H. E., Buzorius, G., Vallius, M., Kreyling, W. G., and Pekkanen, J.: Concentrations of ultrafine, fine and $\mathrm{PM}_{2.5}$ particles in three European cities, Atmos. Environ., 35, 3729-3738, 2001.

Scott, G. M.: The Development of a Methodology for the Delineation of Air Quality Management Areas in South Africa, Ph.D. thesis, University of KwaZulu Natal, Durban, 2010.

Sihto, S.-L., Kulmala, M., Kerminen, V.-M., Dal Maso, M., Petäjä, T., Riipinen, I., Korhonen, H., Arnold, F., Janson, R., Boy, M., Laaksonen, A., and Lehtinen, K. E. J.: Atmospheric sulphuric acid and aerosol formation: implications from atmospheric measurements for nucleation and early growth mechanisms, Atmos. Chem. Phys., 6, 4079-4091, doi:10.5194/acp-6-4079-2006, 2006.

Sipilä, M., Brendt, T., Petäjä, T., Brus, D., Vanhanen, J., Stratmann, F., Patokoski, J., Mauldin III, R. L., Hyvärinen, A.-P., Lihavainen, H., and Kulmala, M.: The role of sulphuric acid in atmospheric nucleation, Science, 32, 1243-1246, 2010.

Stanier, C. O., Khlystov, A. Y., and Pandis, S. N.: Ambient aerosol size distributions and number concentrations measured during the Pittsburgh Air Quality Study (PAQS), Atmos. Environ., 38, 3275-3284, 2004.

Suni, T., Kulmala, M., Hirsikko, A., Bergman, T., Laakso, L., Aalto, P. P., Leuning, R., Cleugh, H., Zegelin, S., Hughes, D., van Gorsel, E., Kitchen, M., Vana, M., Hõrrak, U., Mirme, S., Mirme, A., Sevanto, S., Twining, J., and Tadros, C.: Formation and characteristics of ions and charged aerosol particles in a native Australian Eucalypt forest, Atmos. Chem. Phys., 8, 129-139, doi:10.5194/acp-8-129-2008, 2008.

Svenningsson, B., Arneth, A., Hayward, S., Holst, T., Massling, A., Swietlicki, E., Hirsikko, A., Junninen, H., Riipinen, I., Vana, M., Dal Maso, M., Hussein, T., and Kulmala, M.: Aerosol particle formation events and analysis of high growth rates observed above a subarctic wetland-forest mosaic, Tellus, 60B, 353-364, 2008.

Tyson, P. D., Garstang, M., and Swap, R.: Large-scale re-circulation of air over southern Africa, J. Appl. Meteorol., 35, 2218-2236, 1996.

Vakkari, V., Laakso, H., Kulmala, M., Laaksonen, A., Mabaso, D., Molefe, M., Kgabi, N., and Laakso, L.: New particle formation events in semi-clean South African savannah, Atmos. Chem. Phys., 11, 3333-3346, doi:10.5194/acp-11-3333-2011, 2011.

Venter, A. D., Vakkari, V., Beukes, J. P., van Zyl, P. G., Laakso, H., Mabaso, D., Tiitta, P., Josipovic, M., Kulmala, M., Pienaar, J. J., and Laakso, L.: An air quality assessment in the industrialized western Bushveld Igneous Complex, South Africa, S. Afr. J. Sci., accepted, 2012.

Virkkula, A., Hirsikko, A., Vana, M., Aalto, P. P., Hillamo, R., and Kulmala, M.: Charged particle size distributions and analysis of particle formation events at the Finnish Antarctic research station Aboa, Boreal Environ. Res., 12, 397-408, 2007.

Weber, R. J., Marti, J. J., McMurry, P. H., Eisele, F. L., Tanner, D. J., and Jefferson, A.: Measured atmospheric new particle formation rates: Implications for nucleation mechanisms, Chem. Eng. Commun, 151, 53-64, 1996.

Wehner, B. and Wiedensohler, A.: Long term measurements of submicrometer urban aerosols: statistical analysis for correlations with meteorological conditions and trace gases, Atmos. Chem. 
Phys., 3, 867-879, doi:10.5194/acp-3-867-2003, 2003.

Wenig, M., Spichtinger, N., Stohl, A., Held, G., Beirle, S., Wagner, T., Jähne, B., and Platt, U.: Intercontinental transport of nitrogen oxide pollution plumes, Atmos. Chem. Phys., 3, 387-393, doi:10.5194/acp-3-387-2003, 2003.

Winklmayr, W., Reischl, G., Lindner, A., and Berner, A.: A new electromobility spectrometer for the measurement of aerosol size distributions in the size range from 1 to $1000 \mathrm{~nm}$, J. Aerosol Sci., 22, 289-296, 1991.

Woo, K. S., Chen, D. R., Pui, d. Y. H., and McMurry, P. H.: Measurement of Atlanta aerosol size distributions: observations of ultrafine particle events, Aerosol Sci. Technol., 34, 75-87, 2001.

Wu, Z., Hu, M., Lin, P., Wehner, B., and Wiedensohler, A.: Particle number size distribution in the urban atmosphere of Beijing, China, Atmos. Environ., 42, 7967-7980, 2008.

Wu, Z., Hu, M., Yue, D., Wehner, B., and Wiedensohler, A.: Evolution of particle number size distribution in an urban atmosphere during episodes of heavy pollution and new particle formation, Science China, Earth Sciences, 54, 1772-1778, 2011.

Xiao, Z. and Laplante, A. R.: Characterizing and recovering the platinum group minerals - a review, Miner. Eng., 17, 961-979, 2004.

Yli-Juuti, T., Riipinen, I., Aalto, P. P., Nieminen, T., Maenhaut, W., Janssens, I. A., Clayas, M., Salma, I., Ocskay, R., Hoffer, A., Imre, K., and Kulmala, M.: Characteristics of new particle formation events and cluster ions at K-Puszta, Hungary, Boreal Environ. Res., 14, 683-698, 2009.
Yli-Juuti, T., Nieminen, T., Hirsikko, A., Aalto, P. P., Asmi, E., Hõrrak, U., Manninen, H. E., Patokoski, J., Dal Maso, M., Petäjä, T., Rinne, J., Kulmala, M., and Riipinen, I.: Growth rates of nucleation mode particles in Hyytiälä during 20032009: variation with particle size, season, data analysis method and ambient conditions, Atmos. Chem. Phys., 11, 12865-12886, doi:10.5194/acp-11-12865-2011, 2011.

Yu, F., Luo, G., Bates, T. S., Andersson, B., Clarke, A., Kapustin, V., Yantosca, R. M., Wang, Y., and Wu, S.: Spatial distributions of particle number concentrations in the global troposphere: Simulations, observations, and implications for nucleation mechanism, J. Geophys. Res., 115, D17205, doi:10.1029/2009JD013473, 2010.

Yue, D., Hu, M., Wu, Z., Wang, Z., Guo, S., Wehenr, B., Nowak, A., Achtert, P., Wiedensohler, A., Jung, J., Kim, Y. J., and Liu, S.: Characteristic of aerosol size distributions and new particle formation in the summer in Beijing, J. Geophys. Res., 114, D00G12, doi:10.1029/2008JD010894, 2009. 